\title{
Association of Late Life Depression, (Non-) Modifiable Risk and Protective Factors with Dementia and Alzheimer's Disease: Literature Review on Current Evidences, Preventive Interventions and Possible Future Trends in Prevention and Treatment of Dementia
}

\author{
Chih-Yun Kuo ${ }^{1, *}$, Ivo Stachiv ${ }^{2,3, *(1)}$ and Tomas Nikolai ${ }^{1}$ \\ 1 Department of Neurology and Centre of Clinical Neuroscience, First Faculty of Medicine, Charles University, \\ 12108 Prague, Czech Republic; tomas.nikolai@lf1.cuni.cz \\ 2 Institute of Physics, Czech Academy of Sciences, 18221 Prague, Czech Republic \\ 3 Drážní revize s.r.o., Místecká 1120/103, 70300 Ostrava-Vitkovice, Czech Republic \\ * Correspondence: ginny@draznirevize.cz (C.-Y.K); stachiv@fzu.cz (I.S.)
}

Received: 11 August 2020; Accepted: 6 October 2020; Published: 14 October 2020

check for updates

\begin{abstract}
The number of people living with dementia and Alzheimer's disease is growing rapidly, making dementia one of the biggest challenges for this century. Many studies have indicated that depression plays an important role in development of dementia, including Alzheimer's disease; depression, especially, during the late life may either increase the risk of dementia or even being its prodromal stage. Despite a notably large number of carried observational studies and/or clinical trials, the association between the late life depression and dementia remains, due to the complexity of their relationship, still unclear. Moreover, during past two decades multiple other (non-)modifiable risk and possibly protective factors such as the hypertension, social engagement, obesity, level of education or physical (in)activity have been identified and their relationship with the risk for development of dementia and Alzheimer's disease has been extensively studied. It has been proposed that to understand mechanisms of dementia and Alzheimer's disease pathogeneses require their multifactorial nature represented by these multiple factors to be considered. In this review, we first summarize the recent literature findings on roles of the late life depression and the other known (non-)modifiable risk and possibly protective factors in development of dementia and Alzheimer's disease. Then, we provide evidences supporting hypotheses that (i) depressive syndromes in late life may indicate the prodromal stage of dementia (Alzheimer's disease) and, (ii) the interplay among the multiple (non-)modifiable risk and protective factors should be considered to gain a better understanding of dementia and Alzheimer's disease pathogeneses. We also discuss the evidences of recently established interventions considered to prevent or delay the prodromes of dementia and provide the prospective future directions in prevention and treatment of dementia and Alzheimer's disease using both the single-domain and multidomain interventions.
\end{abstract}

Keywords: dementia; Alzheimer's disease; late life depression; apolipoprotein E; testosterone; obesity; social engagement; substance abuse

\section{Introduction}

Life expectancy that doubled in the past two centuries, and is often considered one of the major achievements of mankind in modern history. This achievement, contributed by fast progress 
in medicine, has not only helped increase longevity, but also brought new challenges to society and national health care systems due to the increased number of people living with cardiovascular diseases [1,2], cancer [2] or depression [3-5]. Depression, particularly in late life, is highly prevalent and is commonly believed being a risk factor for development of dementia [6-10]. Psychiatrists expect the number of people with dementia to almost triple over the next 30 years [11,12].

Deaths related to Alzheimer's disease (AD), the most common ( $60 \%$ cases) and the costliest to the national health care systems type of dementia, have increased by more than $100 \%$ in the past decade [11]. Majority of people with AD suffer with other complications such as cardiovascular diseases $[12,13]$ or diabetes mellitus $[14,15]$; therefore, they may require longer stays in hospitals equipped with advanced nursing facilities and specially trained stuff. The expected further growth of people with $\mathrm{AD}$ would have a strong impact on society, making $\mathrm{AD}$ one of the biggest global challenges of the 21st century [16]. Despite the enormous efforts for finding a cure, AD is still a non-preventable and irreversible form of dementia causing cognitive and functional changes that, in turn, impair individuals' daily life functioning.

During the past few decades researchers have identified multiple other (non-)modifiable risk and protective factors. Since the early stage diagnoses with the relevant interventions may help to significantly delay the prodromes of dementia [17-20], therefore the association of the other (non-) modifiable risk and protective factors with dementia has been also extensively studied. In addition, there is an increasing amount of evidence supporting the relationship between a "healthy" lifestyle (e.g., physical activities and social engagement) and a reduced risk for the development of dementia in later life [21-23]. We emphasize here that the healthy lifestyle is of great importance because dementia and $\mathrm{AD}$ are both the heterogeneous disorders caused by a combination of the multiple (non-)modifiable factors and, as such, the oldest-old people (80+) often have mixed dementia, very complicated to treat [21].

The aim of this review is to provide a literature overview of the most recent findings on roles of each of the already identified (non-)modifiable risk and possibly protective factors in the risk for development of dementia and AD. We first discuss the current understanding of how the late life depression may be associated with dementia. Then, in the following section the relationships among the other (non-)modifiable risk factors, possibly protective factors, and dementia (AD) including the currently considered interventions and the foreseen studies are given. Finally, in the last part of this review, we briefly summarize the prospective future trends and directions in the prevention, treatment and research of dementia and $\mathrm{AD}$ using single-domain and multidomain interventions.

\section{Methods}

We remind the reader that in contrast to a systematic review, where an exhaustive (complete) summary of the recent literature to a very specific question or questions is given, the purpose of present review is to provide the available and most relevant evidence associating the (non-) modifiable risk factors with development of dementia and AD. This review, therefore, does not answer more specific questions related to the relationship among the (non-)modifiable risk factors and development of dementia and $\mathrm{AD}$ (e.g., whether the positive air pressure treatment of sleep disorders can affect the progress of $\mathrm{AD}$ [24]). The literature search was performed among the main worldwide electronic databases, that is, PubMed, Google Scholar, Scopus and the Cochrane Library. Importantly, the search criteria and screening of potential studies were in accordance with the PRISMA extension for scoping review [25]. As a result, the following key terms mainly in the form of the corresponding medical subject heading term (MeSH) were searched: "Alzheimer" or "Alzheimer's disease" or "AD" or "dementia" or "vascular dementia" or "Lewy body dementia" or "dementia/prevention and control" and "depression" or "non-modifiable risk factor" or "risk factor" or "modifiable risk factor" or "protective factor" or "apolipoprotein E (APOE)" or "APOE gene" or "sex hormones" or "estrogen" or "testosterone" or "obesity" or "hypertension" or "social engagement" or "diabetes mellitus" or "education" or "alcohol" or "smoking" or "drugs" or "sleep disturbance" or "obstructive sleep apnea", "eHealth". 
The inclusion criteria for this study were: (i) studies written in the English language; (ii) studies that had undergone a standard peer-review process; and (iii) reports issued by governments or global health care organizations. Similarly, the exclusion criteria were as follows: (i) non-English studies; (ii) non-peer-reviewed studies; (iii) duplicate results; (iv) conference papers or proceedings; (v) studies that did not use standard measurement tools; (vi) studies without methodology or clearly explained findings; and (vii) reports from suspicious non-profit organizations (i.e., non-profit organizations without a clearly defined structure, funding sources, etc.) or studies published in "potentially" predatory journals (i.e., journals are not included in SCIE, that do not have clear review policy, have inappropriate ISSN, etc.). In addition to the inclusion and exclusion criteria, we considered only the most recent and relevant studies in each of the considered topics. Besides, when multiple studies of different authors evidencing similar findings were found, we included only those studies which were accepted first for the publication (i.e., the date of acceptance was considered). Our further in-depth comprehensive review of the selected studies (i.e., those satisfying the inclusion and exclusion criteria) included study objective(s), design, year of the publication, country where study was carried out, the sample size, the main findings, etc. Finally, the key findings of studies satisfying all the inclusion and exclusion criteria and other additional criteria are summarized in Tables 1-6.

\section{Relationship between the Late Life Depression and Dementia (Alzheimer's Disease)}

Depression and dementia, which are the most common mental health problems in the elderly, have a complicated relationship that is not yet fully understood. We remind the reader that depression causes cognitive changes, while dementia is frequently accompanied by various mood symptoms [26,27]. Whether late life depression does or does not increase the risk of dementia, has become a fundamental question that is still undergoing extensive investigation. Most studies performed during past 30 years on depression and dementia are based on scores from existing self-report questionnaires used as depression screening tests [28-31]. The main limitation of these epidemiological studies is usually the relatively short follow-up period between the assessment of depression and the prodromes of dementia [31-36]. Some of these earlier investigations have suggested that the late life depression increases the risk of dementia and AD [37-40]. This conclusion was also supported by the well-known study of Ownby et al. [41], where, based on systematic meta-analysis and metaregression analysis, the authors found that individuals with a history of depression would be more likely to be diagnosed with dementia in later life. Evidences from other studies have, however, indicated that depression either has only a mild effect on dementia [42], does not increase the risk for development of dementia [43] or can be even the prodromal stage of dementia [44,45]. It is worth noting that severity and frequency of depression, differences in the sample sizes and types (e.g., women and men, education level), the culture and ethnical differences (e.g., Sweden, Finland, UK, USA, Australia, Japan, Taiwan), variation in used measures (e.g., operationalization and definition of depression) and different study lengths could be the main reasons for all these inconsistencies.

A majority of psychologists and psychiatrists agree that longer follow-up studies back at least into the midlife period are needed to clarify the relationship between a history of depression and the prodromes of dementia. In response, several long-term prospective cohort studies on depression and dementia have been recently performed [20,45-48]. Among them only a 17-years follow-up cohort study has indicated that depressive symptoms in older individuals can nearly double the risk for development of dementia and/or AD [45]. The main strength of this study is a well characterized cohort. Nevertheless, due to the unknown duration of the depressive symptoms, uneven patient adherence to depression treatment using antidepressants and no possibility of controlling other depressive factors such as the physical and social engagement of the individuals, which are discussed in details in the following section, the authors could still not eliminate the possibility that depression might be just the prodromal stage of dementia. Findings of other long-term cohort studies support the hypothesis that late life depression can be indeed the long and progressive prodromal symptom of dementia [20,47-49]. Especially, Singh-Manoux et al. [49] in their 28-year long follow-up study have proposed that depression 
and dementia share the same common risk factors. Since depressive symptoms such as a lack of motivation or depressed mood occur first, therefore they have suggested that these symptoms should be considered just the prodromal states of dementia and not its early triggers.

Although the additional long-term systematic investigations are still needed to support their conclusions, preliminary findings of these long-term cohort studies may already open a pathway for an early stage diagnosis of dementia, that is, an early stage diagnosis of dementia may require tracing the depressive symptoms back to the at least midlife. For readers' convenience, the main findings of studies associating the late life depression with development of dementia and AD that are discussed in this section, are summarized in Table 1.

Table 1. Main findings of studies associating the late life depression and dementia (Alzheimer's disease).

\begin{tabular}{|c|c|c|c|}
\hline Study & $\begin{array}{l}\text { Sample } \\
\text { Size/Study } \\
\text { Length }\end{array}$ & Measures/Design Questionnaire & $\begin{array}{c}\text { Diagnosis/[OR/HR] Depression } \\
\text { Status }\end{array}$ \\
\hline $\begin{array}{l}\text { Van Wanrooij, } \\
\text { et al. [26] }\end{array}$ & $\begin{array}{l}3299(\mathrm{~F}: 1490 \\
\text { M: } 1490) / 6.7 \\
\text { Years }\end{array}$ & $\begin{array}{l}\text { Geriatric Depression Scale apathy } \\
\text { (GDS-3A); } 12 \text { depression (GDS-12D); } \\
\text { The AMC Linear Disability Score }\end{array}$ & VAD/not discussed \\
\hline Balsis et al. [27] & $\begin{array}{c}108 / 5.26 \text { Years } \\
(3.68 ; 7.97 ; 4.12)\end{array}$ & $\begin{array}{l}\text { Blessed Dementia Scale; Five-factor } \\
\text { model of personality }\end{array}$ & $\mathrm{AD} /$ not discussed \\
\hline Barnes et al. [29] & $\begin{array}{l}2220(\mathrm{~F}: 1319 ; \\
\text { M: } 901) / 6 \text { Years }\end{array}$ & $\begin{array}{c}\text { MCI; MMSE; MRI; Digit Symbol Test, } \\
\text { Benton Visual Retention Test, } \\
\text { Telephone Interview; Center for } \\
\text { Epidemiological }\end{array}$ & $\begin{array}{c}\text { VAD \& Cardiovascular } \\
\text { disease/Moderate Depressive OR: } \\
\text { 1.37 [95\% CI = 1.00-1.88]; High } \\
\text { Depressive OR: } 2.09 \\
\text { [95\% CI = } 1.46-2.97] \text { Associated } \\
\text { with MCI }\end{array}$ \\
\hline Johnson et al. [30] & $\begin{array}{l}\text { 2963/length not } \\
\text { specified }\end{array}$ & $\begin{array}{l}\text { Neuropsychiatric Inventory } \\
\text { Questionnaire }\end{array}$ & $\begin{array}{c}\text { AD: 2474; Parkinson Disease } \\
\text { dementia: } 74 \text {; Dementia with Lewy } \\
\text { bodies: 151; VAD: } 85-\end{array}$ \\
\hline $\begin{array}{l}\text { Leoutsakos et al. } \\
\text { [31] }\end{array}$ & $\begin{array}{c}328(\mathrm{~F}: 216 ; \\
\text { M: 112)/3.7 Years }\end{array}$ & MMSE; Clinical Dementia Rating & $\mathrm{AD} /$ not discussed \\
\hline Gatz et al. [32] & $\begin{array}{l}766 \text { (F: 511; } \\
\text { M: 255)/5 Years }\end{array}$ & $\begin{array}{l}\text { CES-D, participant-reported medical } \\
\text { history, and duration of depression }\end{array}$ & $\begin{array}{c}\text { AD/Adjusted OR: } 1.50 \\
\text { [95\% CI = 0.49-4.63]; Dementia } \\
\text { OR:1.84 [95\% CI = 0.76-4.47] }\end{array}$ \\
\hline Geerlings et al. [34] & $\begin{array}{l}3147 \text { (F: } 1929 ; \\
\text { M: } 1218) / 3.2 \\
\quad \text { Years }\end{array}$ & CES-D; MMSE & $\begin{array}{l}\text { AD/Adjusted OR:1.67 } \\
{[95 \% \mathrm{CI}=0.76-3.63]}\end{array}$ \\
\hline Burke et al. [36] & $\begin{array}{l}\text { 12,053 (F: 7865; } \\
\text { M:4188)/10 Years }\end{array}$ & Clinical Rating Scale & AD/HR: 2.32 [95\% CI, 1.87-2.88] \\
\hline Barca et al. [38] & $\begin{array}{l}282 \text { (F: } 152 ; \mathrm{M}: \\
\text { 130)/2 Years }\end{array}$ & $\begin{array}{l}\text { Cornell Scale for Depression in } \\
\text { Dementia; Clinical Dementia Rating } \\
\text { Scale; MRI; MMSE. }\end{array}$ & $\begin{array}{c}\mathrm{AD} / \text { Depressive symptoms on the } \\
\text { Cornell Scale average probabilities } \\
\text { above } 0.80\end{array}$ \\
\hline Kaup et al. [40] & $\begin{array}{l}2488 \text { (F:1332; M: } \\
\text { 1156)/1 Year }\end{array}$ & $\begin{array}{l}\text { Center for Epidemiologic Studies } \\
\text { Depression Scale Short Form } \\
\text { (CES-D-10); Modified MMSE }\end{array}$ & $\begin{array}{l}\text { Dementia/HR: } 1.94 \\
{[95 \% \mathrm{CI}=1.30-2.90]}\end{array}$ \\
\hline Ownby et al. [41] & $\begin{array}{c}102,172(20 \\
\text { studies)/length } \\
\text { not specified }\end{array}$ & $\begin{array}{c}\text { Meta-analysis \& meta-regression } \\
\text { analysis }\end{array}$ & $\begin{array}{l}\text { AD/Coefficient, } 0.003 ; \text { SE, } 0.001 \\
\qquad \mathrm{z}=2.01 ; p=0.05\end{array}$ \\
\hline Tapainen et al. [42] & $\begin{array}{l}\text { 27,948 (F: } 18,934 ; \\
\text { M: } 9014) / 43 \text { Years } \\
\text { (medical records } \\
\text { from 1972) }\end{array}$ & ICD-8, ICD-9 and ICD-10 & $\begin{array}{c}\mathrm{AD} / 5 \text {-year } \mathrm{AD} \text { adjusted } \mathrm{OR}=1.17 \\
{[95 \% \mathrm{CI}=1.05-1.30] ; 10 \text {-years }} \\
\text { adjusted } \mathrm{OR}=1.08 \\
{[95 \% \mathrm{CI}=0.96-1.23]}\end{array}$ \\
\hline
\end{tabular}


Table 1. Cont.

\begin{tabular}{|c|c|c|c|}
\hline Study & $\begin{array}{l}\text { Sample } \\
\text { Size/Study } \\
\text { Length }\end{array}$ & Measures/Design Questionnaire & $\begin{array}{c}\text { Diagnosis/[OR/HR] Depression } \\
\text { Status }\end{array}$ \\
\hline Becker et al. [43] & 288/7.1 Years & CES-D; Modified MMSE & $\begin{array}{c}\text { AD/Persistent depression HR: } 1.33 \\
\text { [95\% CI = 0.49-3.65]; Transient } \\
\text { depression HR: } 1.62 \\
{[95 \% \mathrm{CI}=0.78-3.35]}\end{array}$ \\
\hline $\begin{array}{l}\text { Brommelhoff et al. } \\
\text { [44] }\end{array}$ & $\begin{array}{c}547(\mathrm{~F}: 372 ; \\
\text { M: } 175) / 4 \text { Years }\end{array}$ & $\begin{array}{l}\text { TELE cognitive screening instrument; } \\
\text { Blessed Dementia Rating Scale }\end{array}$ & $\begin{array}{l}\text { Dementia/OR:1.72 } \\
{[95 \% \mathrm{CI}=1.07-2.76]}\end{array}$ \\
\hline Saczynski et al. [46] & $\begin{array}{c}\text { 164 (F: 104; } \\
\text { M: 60)/17 Years }\end{array}$ & CES-D & $\begin{array}{c}\text { Dementia \& AD/Dementia HR: } 1.72 \\
\text { [95\% CI = 1.04-2.84]; } \\
\text { AD HR: } 1.76 \text { [95\% CI = 1.03-3.01] }\end{array}$ \\
\hline Li et al. [47] & $\begin{array}{c}685(\mathrm{~F}: 408 \\
\text { M: } 250) / 15 \text { Years }\end{array}$ & $\begin{array}{l}\text { Cognitive Abilities Screening } \\
\text { Instrument; CES-D }\end{array}$ & $\begin{array}{c}\text { Dementia/Late life depression: HR: } \\
\text { 1.46 [95\% CI = 1.16-1.84]; Early life } \\
\text { depression: HR: } 1.10 \\
{[95 \% \mathrm{CI}=0.83-1.47] \text { history of }} \\
\text { depression early-life }(<50 \text { years })\end{array}$ \\
\hline Amieva et al. [48] & $\begin{array}{c}350(\mathrm{~F}: 242 \\
\mathrm{M}: 108) / 14 \text { Years }\end{array}$ & $\begin{array}{l}\text { Isaacs Set Test (IST); Benton Visual } \\
\text { Retention Test; MMSE; Wechsler } \\
\text { Similarities test; Instrumental } \\
\text { activities of daily living }\end{array}$ & $\mathrm{AD} /$ not discussed \\
\hline $\begin{array}{l}\text { Singh-Manoux et al. } \\
{[49]}\end{array}$ & $\begin{array}{l}\text { 10,189 (F: 3351; } \\
\text { M: 6838) }\end{array}$ & $\begin{array}{l}\text { 30-item General Health Questionnaire } \\
\text { (GHQ-30); CES-D }\end{array}$ & $\begin{array}{l}\text { Dementia/Those reporting } \\
\text { depressive symptoms in } 1985 \mathrm{HR} \text { : } \\
1.21 \text { [95\% CI = 0.95-1.54]; Those } \\
\text { reporting depressive symptoms in } \\
2003 \text { HR: } 1.72 \text { [ } 95 \% \text { CI, } 1.21-2.44]\end{array}$ \\
\hline
\end{tabular}

\section{Other Established (Non-)Modifiable Risk Factors and Possibly Protective Factors and Their Association with Dementia and Alzheimer's Disease}

\subsection{Association of Genetic Predisposition and Sex Hormones with Dementia and Alzheimer Disease}

The risk for development of dementia increases exponentially with advancing age. As a result, majority of the oldest-old people is afflicted with at least one type of dementia such as Alzheimer's disease or vascular dementia [50]. Age is, therefore, considered to be the strongest non-modifiable risk factor for development of dementia. Numerous clinical studies have proposed that a low level of apolipoprotein E (APOE) genotype [51-53] along with its genetic variations [54,55] increases the risk of dementia; especially for individuals where dementia has been diagnosed in first-degree relatives (see Table 2). The APOE, which is co-responsible for carrying various fats such as cholesterol through the bloodstream, plays an important role in regulation of the neurotoxic amyloid beta (A $\beta$ ) peptide. It alters the brain activity and metabolism (e.g., removal of amyloid plagues) and, correspondingly, a low level of APOE is then associated with the progress in cognitive decline (i.e., it enhances the structural and functional changes in brain that are known to be linked with an early sign of AD neuropathology). The higher risk for development of dementia may be also explained by interaction between the genetic and environmental factors [56]. It is worth noting that the association between a low APOE level and the higher risk of dementia has been recently supported by a Mendelian randomization study performed on two large population cohorts (106,562 and 75,260 individuals) [57]. 
Table 2. Effect of the genetic predisposition and changes in sex hormones levels on the risk of dementia/AD.

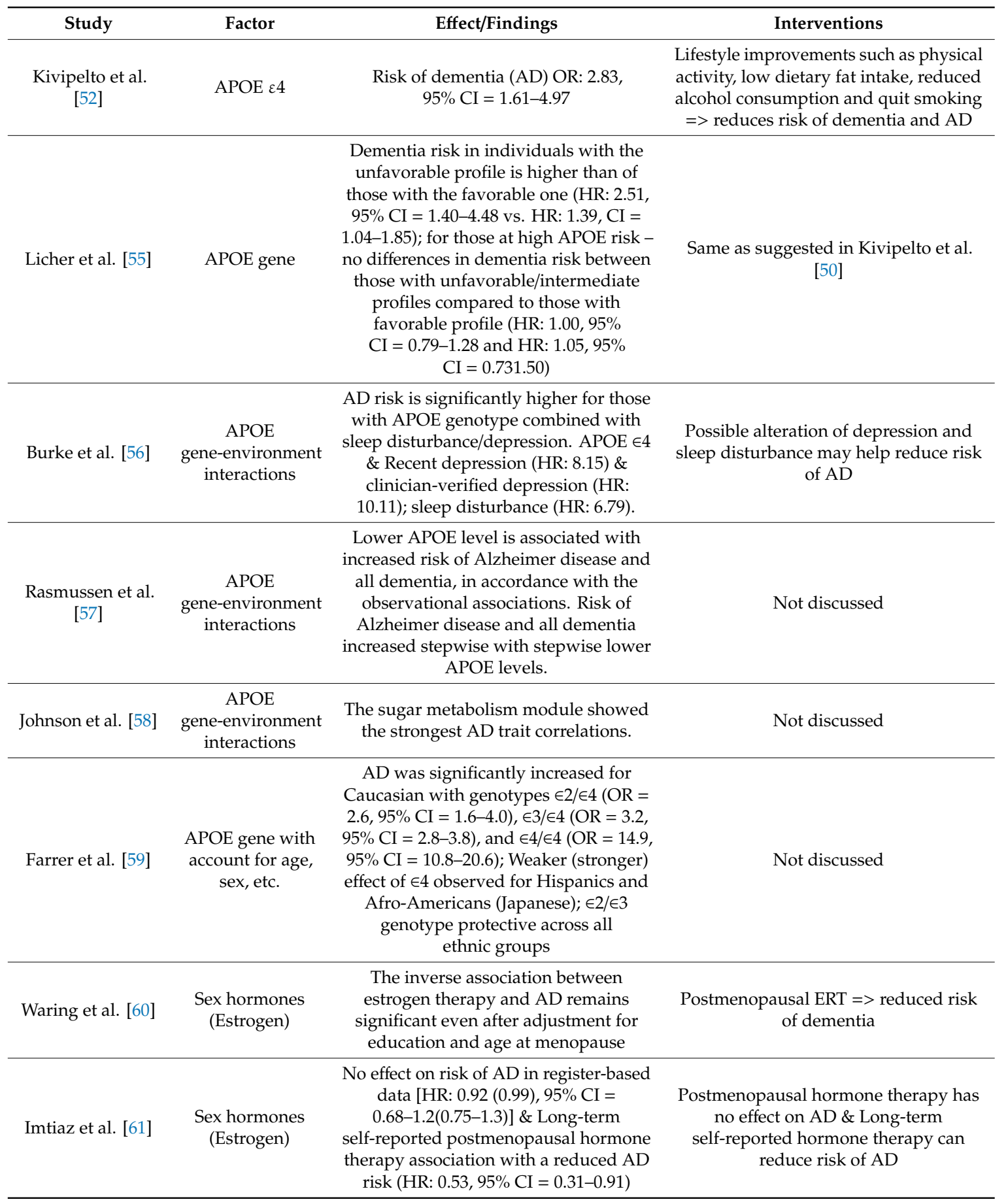


Table 2. Cont.

\begin{tabular}{|c|c|c|c|}
\hline Study & Factor & Effect/Findings & Interventions \\
\hline Shao et al. [63] & $\begin{array}{l}\text { Sex hormones } \\
\text { (Estrogen) }\end{array}$ & $\begin{array}{l}\text { Hormone therapy and reduced risk of } \\
\text { AD depend on timing of use. Hormone } \\
\text { therapy started within } 5 \text { years of } \\
\text { menopause associated with significantly } \\
\text { lower AD risk (HR: } 0.70 ; 95 \% \mathrm{CI}=0.49- \\
\text { 0.99) \& Hormone therapy started later } \\
\text { than } 5 \text { years showed no such association } \\
\text { (HR:1.03; } 95 \% \mathrm{CI}=0.68-1.55 \text { ). }\end{array}$ & $\begin{array}{l}\text { Early (in } 5 \text { years) use of hormone } \\
\text { therapy }=>\text { reduces risk of AD; Late } \\
\text { (more than } 5 \text { years) use of hormone } \\
\text { therapy }=>\text { increased risk of AD }\end{array}$ \\
\hline Ford et al. [65] & $\begin{array}{l}\text { Sex hormones } \\
\text { (Testosterone) }\end{array}$ & $\begin{array}{l}\text { Risk of dementia increases with } \\
\text { decrease of testosterone level (HR: 1.14, } \\
95 \% \mathrm{CI}=1.03-1.26)\end{array}$ & $\begin{array}{c}\text { Testosterone treatment may improve } \\
\text { cognition or prevent further cognitive } \\
\text { decline. }\end{array}$ \\
\hline $\begin{array}{l}\text { Carcaillon et al. } \\
{[66]}\end{array}$ & $\begin{array}{l}\text { Sex hormones } \\
\text { (Testosterone) }\end{array}$ & $\begin{array}{l}\text { No significant association was found } \\
\text { between Total-17-b estradiol and } \\
\text { dementia/low testosterone level } \\
\text { increases risk of dementia in men }\end{array}$ & Not discussed \\
\hline
\end{tabular}

OR-Odds ratio; HR- Hazard ratio; CI - Confidence interval; RR - Relative risk; AD - Alzheimer's disease.

Deposition of the neurotoxic amyloid beta and alteration of $t$-tau proteins levels that may impair the cognitive functioning of the individuals and subsequently lead to dementia are known to be long-term processes (i.e., alteration in cerebrospinal fluid has been recently observed even for individuals in the asymptomatic stage of $\mathrm{AD}$ [58]). Hence, it can be of great importance to perform long-term investigations on how the APOE level and cerebrospinal fluid changes in the early-, mid- and late-life are connected with a higher/lower risk for development of dementia. We emphasize here that this kind of studies would probably require, in addition to the standard psychiatric and psychological methods, the development of novel brain activity mapping techniques [67], along with mass spectrometry in gaseous or aqueous solutions [68].

Some studies have observed that the risk factors and progression of dementia are also genderdependent. Females are generally more vulnerable to genetic and environmental risk factors than males, resulting in a higher prevalence of dementia in elderly women $[59,69]$. Moreover, it has been found that females are in a greater risk for development of $\mathrm{AD}$, whereas males have a higher chance of vascular dementia. Sex difference as the risk factor for the development of dementia and the underlying mechanisms are not yet fully understood. It could probably be caused by a combination of several factors, including the developmental and physiological differences between males and females (e.g., the environmental stimuli and exposure to various hormones may create gender-sex differences in the brain structures) and lifetime sex hormone level changes (e.g., a significant drop of the estrogen level after menopause) [70]. Estrogen increases the cerebral blood flow and has the neuroprotective properties. It plays the important role in regulation of $A \beta$ peptide against oxidative stress and neuroinflammation. As a result, estrogen has a beneficial effect on the cognitive functions and helps to improve the cognitive dysfunction observed in AD individuals. Surprisingly, effectiveness of the postmenopausal hormone-based therapy on delay the prodromes of dementia remains uncertain. While earlier population-based studies suggested that postmenopausal hormone therapy reduces the risk for development of dementia [60], the results of more recent studies have indicated that 
postmenopausal hormone therapy either does not reduce [61] or may even increase the risk of dementia [62]. The inconsistency in these findings may be explained by a significantly different effect of the hormone therapy timing after menopause. For example, about $30 \%$ lower chance for AD was observed for females using hormone therapy within 5 years of menopause, whereas for those using the hormone therapy after 5 or more years of menopause the opposite effect was found, that is, a higher risk for development of $\mathrm{AD}$ [63].

Testosterone, the male sex hormone, is neuroprotective and it contributes to the removal of $A \beta$ peptide. Low testosterone levels are often associated with vascular problems, heart attacks, strokes or depression. Hence, elderly males with a low level of sex hormone are more vulnerable to cognitive impairment and, correspondingly, may be at a higher risk of dementia [64]. This hypothesis has been recently supported by a 10+ years follow-up cohort study performed on 4069 males [65]. Interestingly, some other earlier studies provided evidence associating low testosterone and an increased risk of dementia just in males with either a high education level or age over 80 [66]. It is expected that testosterone therapy might help to reduce the risk of dementia in elderly males. Unfortunately, an earlier clinical study has provided evidence supporting only a mild effect of testosterone treatment on cognitive function [71]. We can therefore easily conclude that a possible future studies topic should be to target the efficiency of hormone therapy (estrogen and testosterone) for different hormone therapy timing and duration, individuals' education level, age, ethnicity, etc. The main findings of studies associating genetic predisposition and changes in the sex hormones with dementia considered in this review are summarized in Table 2.

\subsection{Association of Depression, Obesity, Diabetes Mellitus and Blood Pressure with Dementia and Alzheimer Disease}

Genetic predisposition cannot be notably modified by intervention or the behavioral changes of individuals. The interactions between genes, psychosocial and lifestyle or environmental factors are associated with a higher (lower) risk for later-life dementia. In past decades multiple protective and possibly modifiable risk factors were identified and their associations with dementia studied. A history of depression, obesity, hypertension, diabetes mellitus, dyslipidemia, cardiovascular diseases, sleep disturbances, brain injury, smoking and alcohol misuse are among the best-known modifiable risk factors. For example, some early studies have provided convincing evidence supporting an association between early life and midlife depression with an increased risk of dementia in later life [72]. The weakness of these studies is usually a relatively short follow-up period. In contrast, the results of recently published long-term longitudinal studies do not support an association between midlife depression and an increased risk of dementia [20,48]. Instead, they have considered depression to be the prodromal stage of dementia because they both share similar common neuropathological processes [49]. Recalling that a detailed discussion on the relationship between depression and dementia was presented in the previous section, the association between clinical anxiety in midlife and an increased risk for development of dementia has been also highlighted [73]. Whether clinical anxiety increases the risk of dementia or is just its prodromal stage is, nevertheless, currently still under extensive active investigation (i.e., in ongoing long-term follow-up studies with well-defined cohorts).

The number of individuals with obesity has nearly tripled in past 30 years and in most Western countries obesity has already become prevalent. It has been suggested that the inflammation and oxidative stress caused by obesity affect the brain in the same manner as known for the arteries and/or the inner organs, leading to the neurodegeneration and, subsequently, the development of dementia [74]. As a result, numerous studies have considered midlife obesity as a possible modifiable risk factor for the development of dementia [75-77]. We emphasize here that recent evidence from the results of a 15+ years long prospective study performed on an enormously large cohort of $\sim 1.1$ million individuals supports a strong link between midlife obesity and vascular dementia, whereas no such connection between obesity and AD has been observed [78]. Obesity itself is often associated with other possibly modifiable risk factors including diabetes mellitus or hypertension as shown in Table 3 [79]. 
Diabetes mellitus is a metabolic disorder characterized by insulin resistance or insulin deficiency. During diabetes variations in plasma osmotic pressure and oxidative stress levels may result in cognitive changes in the brain, that is, the imbalance between oxidants and antioxidants initiates neurodegeneration through the excessive deposition of $A \beta$ peptide and the release of free radicals, and, correspondingly, they can lead to dementia $[80,81]$. The preliminary results of recent clinical trial studies have indicated that intranasal insulin therapy may help improve verbal memory, especially, the story recall performance of the APOE genotype [82]. We emphasize here that the main drawback of these studies, performed in one country (USA) is the small cohort, comprising of only 293 individuals. Thus, in order for the promising efficiency of intranasal insulin therapy in the treatment of dementia and AD to be confirmed, additional worldwide clinical studies on a large population cohort still need to be performed.

Table 3. Association of the obesity, diabetes mellitus and hypertension with the risk for development of dementia/Alzheimer's disease.

\begin{tabular}{|c|c|c|c|}
\hline Study & Factor & Effect/Findings & Interventions \\
\hline Xu et al. [75] & Obesity & $\begin{array}{l}\text { Overweight }-\mathrm{OR}=1.71,95 \% \mathrm{CI}= \\
1.30-2.25 \text { and obesity-OR }=3.88 \\
95 \% \mathrm{CI}=2.12-7.11\end{array}$ & $\begin{array}{l}\text { Healthy diet and physical activities to } \\
\text { reduce BMI in midlife to normal level } \\
\text { reduces risk of later life dementia/AD. }\end{array}$ \\
\hline $\begin{array}{l}\text { Albanese et al. } \\
\qquad[76]\end{array}$ & Obesity & $\begin{array}{l}\text { Midlife (age } 35 \text { to } 65 \text { years) obesity } \\
(\mathrm{BMI} \geq 30)(\mathrm{RR}=1.33 ; 95 \% \mathrm{CI}=1.08-1.63) \\
\text { associated with dementia in late life }\end{array}$ & $\begin{array}{l}\text { Same as suggested in } \mathrm{Xu} \text { et al. } \\
\text { [75] }\end{array}$ \\
\hline $\begin{array}{l}\text { Kivimaki et al. } \\
\text { [77] }\end{array}$ & Obesity & $\begin{array}{l}\text { per } 5-\mathrm{kg} / \mathrm{m}^{2} \text { increase in BMI for dementia } \\
\text { was assessed before dementia diagnosis } \\
10 \text { years (HR:0.71, 95\% CI = 0.66-0.77); } \\
10-20 \text { years (HR:0.94, 95\% CI }=0.89-0.99 \text { ); } \\
>20 \text { years (HR:1.16, 95\% CI }=1.05-1.27 \text { ) }\end{array}$ & Not discussed \\
\hline Floud et al. [78] & Obesity & $\begin{array}{l}\text { Dementia detection during years } 15+\text { was } \\
\text { associated with baseline obesity (BMI 30+ } \\
\text { vs. } 20-24 \mathrm{~kg} / \mathrm{m}^{2}: \mathrm{RR}=1.21,95 \% \mathrm{CI}= \\
\qquad 1.16-1.26, p<0.0001)\end{array}$ & $\begin{array}{l}\text { Same as suggested in } \mathrm{Xu} \text { et al. } \\
\text { [75] }\end{array}$ \\
\hline Fan et al. [81] & Diabetes mellitus & $\begin{array}{l}\text { Diabetes mellitus individuals are having } \\
\text { adjusted HR: } 1.47,95 \% \mathrm{CI}=1.30-1.67, p< \\
0.001) \text {, Diabetes mellitus increases notably } \\
\text { risk of dementia }\end{array}$ & $\begin{array}{l}\text { Prevention of comorbidities (e.g., } \\
\text { hypertension and hyperlipidemia) during } \\
\text { diabetes reduces risk of dementia }\end{array}$ \\
\hline $\begin{array}{l}\text { Avgerinos et al. } \\
\text { [82] }\end{array}$ & Diabetes mellitus & $\begin{array}{l}\text { Intranasal insulin improves verbal } \\
\text { memory, its effect differs for apoe } 4 \text { allele } \\
\text { carrier status (i.e., apoe4(-) stronger } \\
\text { cognitive gain than apoe } 4(+))\end{array}$ & $\begin{array}{l}\text { Intranasal insulin intervention reduces } \\
\text { risk of dementia }\end{array}$ \\
\hline Emdin et al. [83] & Hypertension & $\begin{array}{l}\text { Link between usual systolic blood } \\
\text { pressure and risk of vascular dementia } \\
\text { decreases with age (per } 20 \mathrm{~mm} \text { Hg higher } \\
\text { systolic blood pressure, HR:1.62; } \\
95 \% \mathrm{CI}=1.13-2.35 \text { at } 30-50 \text { years; } \\
\text { HR:1.26, CI }=1.18-1.35 \text { at } 51-70 \text { years; } \\
\text { HR:0.97, CI }=0.92-1.03 \text { at } 71-90 \text { years) }\end{array}$ & $\begin{array}{l}\text { Control blood pressure to reduces the risk } \\
\text { of dementia }\end{array}$ \\
\hline Nagai et al. [84] & Hypertension & $\begin{array}{l}\text { Antihypertensive therapy may reduce the } \\
\text { risk of dementia by i) } 11 \%(\mathrm{OR}=0.89 ; \\
95 \% \mathrm{CI}=0.69-1.16) \text { or ii) }(\mathrm{HR}: 0.87 ; 95 \% \\
\mathrm{CI}=0.76-1.00)\end{array}$ & $\begin{array}{l}\text { Blood pressure control during sleep has a } \\
\text { neuroprotective effect on the brain, it } \\
\text { prevents the incidence of dementia. }\end{array}$ \\
\hline $\begin{array}{l}\text { Janelidze et al. } \\
\text { [85] }\end{array}$ & $\begin{array}{l}\text { Hypertension/Plasma } \\
\beta \text {-amyloid }\end{array}$ & $\begin{array}{l}\text { Higher plasma level } A \beta \text { is linked with } \\
\text { hypertension; For } A D \text { patients the levels } \\
\text { of } A \beta 40 \text { and } A \beta 42 \text { were reduced \& } \\
\text { Preclinical or prodromal stage of } A D \\
\text { linked with low } A \beta 42 / A \beta 40 \text { ratio and/or } \\
A \beta 42 \text { plasma level. }\end{array}$ & Not discussed \\
\hline Walker et al. [86] & Hypertension & $\begin{array}{l}\text { Sustained midlife to late-life hypotension } \\
\& \text { midlife hypertension and late-life } \\
\text { hypotension increases risk for subsequent } \\
\text { dementia (HR:1.62, 95\% CI }=1.11-2.37] \text { ) }\end{array}$ & Not discussed \\
\hline
\end{tabular}


Table 3. Association of the obesity, diabetes mellitus and hypertension with the risk for development of dementia/Alzheimer's disease.

\begin{tabular}{|c|c|c|c|}
\hline Study & Factor & Effect/Findings & Interventions \\
\hline $\begin{array}{l}\text { Corrada et al. } \\
\text { [87] }\end{array}$ & Hypertension & $\begin{array}{c}\text { Hypertension onset age } 80 \text { to } 89 \text { - lower } \\
\text { dementia risk (HR: } 0.58 \text {; Onset age of } 90+ \\
\text { lowest dementia risk (HR:0.37); } \\
\text { Developing hypertension at older ages } \\
\text { may protect against dementia }\end{array}$ & Not discussed \\
\hline Gilsanz et al. [88] & Hypertension & $\begin{array}{l}\text { Mid-life hypertension associated with } \\
\sim 65 \% \text { increased dementia risk only among } \\
\text { women but not men. [95\% CI }=1.25-2.18]\end{array}$ & $\begin{array}{c}\text { Hypertension treatment reduces risk of } \\
\text { dementia }\end{array}$ \\
\hline Murray et al. [89] & Hypertension & $\begin{array}{c}\text { Individuals prescribed any } \\
\text { antihypertensive medication have a } \\
\text { significantly reduced risk of dementia } \\
\text { (HR:0.57, } 95 \% \mathrm{CI}=0.37-0.88 \text { ) compared } \\
\text { to untreated hypertension }\end{array}$ & $\begin{array}{l}\text { Antihypertensive medication-Control of } \\
\text { blood pressure reduces risk of dementia }\end{array}$ \\
\hline
\end{tabular}

OR—Odds ratio; HR—Hazard ratio; CI—Confidence interval; RR—Relative risk; AD—Alzheimer's disease.

The cerebral circulation is strongly blood pressure dependent; therefore, the integrity of white matter can be easily impaired by structural changes or damage to the small arteries (e.g., microinfarcts) caused by high (low) blood pressure [90]. This immediately implies that chronic hypertension not only increases the risk for cerebrovascular disorders like cerebral infarcts but also impairs the brain cognitive functions, which in the worse situation could lead to vascular dementia [83]. More recently, an association between high blood pressure and AD has been suggested by numerous studies $[83,84,90-93]$. High blood pressure has been observed to cause an aggregation of the neurotoxic $\mathrm{A} \beta$ peptide in the brain that in time can lead to cerebrovascular disfunction and AD [94]. It has been also found that in contrast to vascular dementia, where an increased level of $A \beta$ peptide is observed, the dementia level of $\mathrm{AD}$ is linked with a low level of $\mathrm{A} \beta$ peptide [85]. This strong impact of midlife chronic hypertension on the increased risk for dementia in later life has been supported by a 24-year follow-up study carried out on 4751 individuals [86]. Surprisingly, a protective function of high blood pressure in the oldest-old has been found for individuals with hypertension developed in late life [87]. The current hypothesis suggests that high blood pressure in the oldest-old compensates for their age-related vascular changes and, consequently, may help to maintain normal cognition. Gilsanz et al. [88] have studied the relationship between midlife hypertension and the prodromes of dementia in terms of sex difference. According their findings, midlife hypertension increases the risk of dementia for females only, while no association between midlife hypertension and dementia in male individuals has been observed. Regrettably, a sufficient amount of evidence supporting both the protective function of hypertension in the oldest-old and sex differences with the risk for development of dementia is still missing. In general, blood pressure can be easily controlled by various medications. Numerous studies have revealed no differences between individuals using anti-hypertensive medications and those without hypertension [89,93]. It has also been observed that the control of blood pressure during the lifetime, especially during sleep, can significantly decrease the risk for development of dementia in later life [84].

Table 3 clearly shows that the risk of cognitive impairment and dementia that is associated with obesity, diabetes (type 2) and hypertension, can be significantly reduced by a combination of a healthy diet and physical activities. Individuals with healthy dietary patterns, that is, a regular intake of fruits, vegetables, whole grains, nuts, and fish are in a reduced risk of later life dementia. The is due to a fact that a healthy dietary pattern with regular physical activity helps individuals keep their body mass index below the obesity level and improve their memory and attention, as well as the other cognitive functions. Future studies may consider investigating the effectiveness of different healthy diet and/or physical activity timing on a reduced risk for the development of dementia and $\mathrm{AD}$ in later life. 


\subsection{The Relationship between Dementia (Alzheimer's Disease) and Education Levels (Social Engagement)}

The brain reserve that enhances the individual's resilience to prevent or delay the prodromes of dementia, is known to be associated with one's level of education [95]. Plenty of studies have suggested that early life education stimulates the brain to build the cognitive reserve, therefore, higher education may help decrease the risk of later life dementia (see Table 4) [96-98]. For example, clear evidence supporting association of the higher education with a lower risk of dementia has been provided by Matthews et al. [99]. In their long-term (two-decades) comparative study earlier born elderly individuals are showing more dementia cases than those born later in the past century. The lower risk for development of dementia in the later born elderly can be explained by a combination of the multiple factors including improvements in the early stage diagnosis of cerebrovascular and heart diseases and the widespread support for early life education during the past century. The autopsy-verified findings from the Nun Study provide additional evidence supporting the beneficial effect of more education on the cognitive functions in later life, even for individuals with AD pathology [100]. The results of other studies have suggested that the non-modifiable genetic predisposition caused by a negative effect of APOE can be noteworthily suppressed in individuals with high education levels [101,102]. The establishment of firm connections between higher education levels and a delay in the prodromes of dementia still requires however further long-term studies.

Table 4. Relationship between the education level/social engagement and the risk for development of dementia or Alzheimer's disease.

\begin{tabular}{|c|c|c|c|}
\hline Study & Factor & Effect/Findings & Interventions \\
\hline Skoog et al. [95] & $\begin{array}{l}\text { Education \& } \\
\text { Hypertension }\end{array}$ & $\begin{array}{c}\text { Education }(\mathrm{OR}=0.70 ; 95 \% \mathrm{CI}=0.51-0.96) \\
\text { stroke }(\mathrm{OR}=3.78 ; 95 \% \mathrm{CI}=2.28-6.29) \\
\text { Higher education increases cognitive } \\
\text { reserve and reduces risk of dementia }\end{array}$ & $\begin{array}{l}\text { Promote the higher education, which } \\
\text { helps to build the cognitive reserve } \\
\text { needed to reduce the risk of dementia }\end{array}$ \\
\hline Xu et al. [96] & Education & $\begin{array}{c}\text { Low education shows a more significant } \\
\text { increment of dementia or AD risk (for } \\
\text { dementia HR: } 1.81 ; 95 \% \mathrm{CI}=1.59-2.06 \& \\
\text { for AD HR:1.78; } 95 \% \mathrm{CI}=1.43-2.22 \text { ); One } \\
\text { year of the additional education reduces } \\
\text { risk of dementia by } \sim 7 \% \text {. }\end{array}$ & Same as suggested in Skoog et al. [95] \\
\hline Nguyen et al. [97] & Education & $\begin{array}{l}\text { There is } \sim 1.1 \% \text { reduction in dementia risk } \\
\text { per year of schooling }(95 \% \mathrm{CI}=2.4-0.02) \text {. }\end{array}$ & Same as suggested in Skoog et al. [95] \\
\hline Then et al. [98] & Education & $\begin{array}{c}\text { Education years } \leq 10 \text { years }=>\text { Dementia } \\
\text { free } 70.4 \% \text {; Education years }>10 \text { years } \\
82.4 \% ;=>\text { Protective effect of more years } \\
\text { of education on a lower dementia risk } \\
\text { with critical threshold of completing }>10 \\
\text { years of education }\end{array}$ & Same as suggested in Skoog et al. [95] \\
\hline Wang et al. [101] & $\begin{array}{l}\text { Education and } \\
\text { Apolipoprotein } \\
\qquad 4\end{array}$ & $\begin{array}{l}\text { High education ( } 8 \text { years and more) was } \\
\text { related to a lower dementia risk }(\mathrm{OR}=0.5 \text {; } \\
95 \% \mathrm{CI}=0.3-0.6) \text {; Higher education } \\
\text { buffers the negative effect of APOE } 4 \text { on } \\
\text { dementia occurrence }\end{array}$ & Same as suggested in Skoog et al. [95] \\
\hline $\begin{array}{l}\text { Appiah et al. } \\
\text { [102] }\end{array}$ & $\begin{array}{l}\text { Education and } \\
\text { Apolipoprotein } \\
\qquad 4\end{array}$ & $\begin{array}{l}\text { Interaction between education and APOE } \\
\text { found; HR of mortality of } \varepsilon 4 \text { carriers vs. } \\
\text { non-carriers => i) HR:1.59, } 95 \% \mathrm{CI}= \\
0.64-3.96 \text { (post)graduate level; HR:6.66, } \\
95 \% \mathrm{CI}=1.90-23.4 \text { college level, HR:14.1, } \\
95 \%, \mathrm{CI}=3.03-65.6 \text { basic or high school } \\
\text { level; Higher education weakens the } \\
\text { adverse effect of } \varepsilon 4 \text { on mortality }\end{array}$ & Same as suggested in Skoog et al. [95] \\
\hline
\end{tabular}


Table 4. Cont.

\begin{tabular}{|c|c|c|c|}
\hline Study & Factor & Effect/Findings & Interventions \\
\hline Saito et al. [104] & $\begin{array}{c}\text { Social } \\
\text { Engagement }\end{array}$ & $\begin{array}{l}\text { Being married, having social support of } \\
\text { family members or friends, joining } \\
\text { community groups, or engaging in work } \\
\text { reduce risk of dementia }\end{array}$ & Same as suggested in Zhou et al. [103] \\
\hline Kuiper et al. [106] & $\begin{array}{c}\text { Social } \\
\text { Engagement }\end{array}$ & $\begin{array}{c}\text { Low social participation }(\mathrm{RR}=1.41,95 \% \\
\mathrm{CI}=1.13-1.75), \text { less frequent social } \\
\text { contact }(\mathrm{RR}=1.57,95 \% \mathrm{CI}=1.32-1.85), \\
\text { and loneliness }(\mathrm{RR}=1.58,95 \% \mathrm{CI}= \\
\text { 1.19-2.09) increase risk of dementia. Low } \\
\text { social engagement has comparable effect } \\
\text { on risk of dementia as observed for low } \\
\text { education, physical in-activities, and } \\
\text { depression. }\end{array}$ & Same as suggested in Zhou et al. [103] \\
\hline Salinas et al. [108] & $\begin{array}{c}\text { Social } \\
\text { Engagement }\end{array}$ & $\begin{array}{l}\text { Reduced risk of dementia in participants } \\
\text { with stronger social network (HR:0.67, } \\
95 \% \text { CI }=0.49-0.92) \text { and greater emotional } \\
\text { support (HR:0.69, 95\% CI = 0.51-0.94) }\end{array}$ & $\begin{array}{l}\text { Same as prosed in Penninkilampi et al. } \\
\text { [107] }\end{array}$ \\
\hline $\begin{array}{l}\text { Murata et al. } \\
\text { [109] }\end{array}$ & $\begin{array}{l}\text { Social } \\
\text { Engagement }\end{array}$ & $\begin{array}{c}\text { Family support on incident dementia } \\
\text { beneficial only for men (HR:0.95 95\% CI = } \\
\text { 0.91-0.99); Family support for women } \\
\text { (HR:1.00 95\% CI = 0.97-1.04) }\end{array}$ & $\begin{array}{l}\text { Promotion of social interaction with } \\
\text { family members reduces risk of dementia }\end{array}$ \\
\hline
\end{tabular}

Table 4 shows that the social engagement of elderly individuals can also play an important role in the prevention of dementia. Individuals with strong social engagement or positive social support from their family members and friends often have a lower risk of getting dementia in later life than those with negative social support or low social engagement [103-107]. The mechanism(s) underlying the connection between social engagement (social support) and the risk of dementia remain unclear, although several hypotheses to explain their relationship have already been proposed. First, social engagement may stimulate cognitive function and help maintain the brain reserves needed to prevent or delay the prodromes of dementia $[95,110]$. Second, this engagement improves the immune system and supports the central nervous system to preserve its internal stability [108]. Positive social support can, particularly, help significantly reduce chronic stress, which is a well-known risk factor for the development of $\mathrm{AD}$, that is, chronic stress causes functional changes in the microglia immune cells, which are co-responsible for the removal of toxic materials from the brain [111]. Third, people with good social engagement are much less vulnerable to other risk factors such as smoking, alcohol misuse, obesity or depressive mood [104]. Some other studies have addressed the role of sex differences in the 
association between social engagement and the risk of dementia. For instance, according the findings of a recent 10-year follow-up study, social engagement decreases the risk of dementia just for male individuals, while for females no any significant effect of social engagement on dementia has been found [109]. Despite its large population sample $(n=14,088)$, this study does not account for the effect of cultural differences (the study was performed just in Japan, where social interactions within the community are significantly different from those known in Western countries), therefore it has been suggested that studies performed in different culture societies would be needed to confirm the general validity of the findings.

We note that in past 30 years we have been witnesses to great advances in communication technology, which have enabled the establishment of new ways of social engagement through the so-called instant messengers, social networking applications or e-mail. As a result, some researchers hypothesize that this novel communication technology may be considered as an alternative way of maintaining cognitive health, particularly for the elderly who are living alone and/or without the family support [112]. Whether the novel communication technology can or cannot delay cognitive decline and, subsequently, help reduce the risk of development of dementia, may be considered as one of the research goals of future studies associating social engagement with dementia.

\subsection{The Relationship between Dementia (Alzheimer's Disease) and Various Drugs}

The acute use of alcohol, legal or illegal drugs like benzodiazepines, cannabis or tobacco smoking may impair individuals' cognitive functions and increase the risk for the development of dementia in later life. The findings of numerous studies have suggested that not only heavy drinkers but also abstainers (the two extreme limits) are at higher risk of later life dementia, whereas individuals consuming light-to-moderate amounts of alcohol may be at lower risk of dementia [113]. The protective effect of light-to-moderate alcohol intake has been supported by a recent 23-year long follow-up study, in which the cohort has been followed back from the middle age [114]. The same effect has been also observed in elderly populations, where moderate drinking may be associated with a lower risk of dementia death than among abstainers [115]. It is not surprising that published studies evaluate the alcohol consumption level based on self-report measures. These studies do not account for the different culture "standards", that is, the meaning of heavy, moderate and light levels of alcohol consumption differs worldwide, and, correspondingly, the obtained findings and conclusions might be easily mispresented. Moreover, alcohol consumption is regarded as a priority issue related to public health and studies investigating associations between alcohol consumption and dementia are either not easy to perform or even restricted. Hence, without a clear understanding of the biological mechanisms underlying the connection between alcohol consumption and the risk of dementia, no conclusions on alcohol drinking can be drawn yet. It is important to note that another recent study provides evidence associating a higher risk of dementia even with the light-to-moderate alcohol consumption [116]. The key findings of the presented studies on alcohol consumption and dementia are summarized in Table 5.

Table 5. Studies associating addictive substances and cigarette smoking with the risk of dementia/Alzheimer's disease.

\begin{tabular}{cccc}
\hline Study & Factor & Effect/Findings & Interventions \\
\hline Xu et al. [113] & $\begin{array}{c}\text { Alcohol } \\
\text { consumption }\end{array}$ & $\begin{array}{c}\text { For individuals bellow age of 60-Modest alcohol } \\
\text { consumption }(\leq 12.5 \mathrm{~g} / \text { day }) \text { linked with a reduced } \\
\text { risk of dementia with } 6 \mathrm{~g} / \text { day of alcohol, heavy } \\
\text { drinking }(\sim 23 \text { drinks/week or } \geq 38 \mathrm{~g} / \text { day }) \text { increases } \\
\text { risk of dementia. }\end{array}$ & Not discussed \\
\hline Sabia et al. [114] & $\begin{array}{c}\text { Alcohol } \\
\text { consumption }\end{array}$ & $\begin{array}{c}\text { Abstinence and heavy drinking in midlife were } \\
\text { both associated with a higher risk of dementia. }\end{array}$ & Not discussed \\
\hline
\end{tabular}


Table 5. Cont.

\begin{tabular}{|c|c|c|c|}
\hline Study & Factor & Effect/Findings & Interventions \\
\hline $\begin{array}{l}\text { Ormstad et al. } \\
{[115]}\end{array}$ & $\begin{array}{c}\text { Alcohol } \\
\text { consumption }\end{array}$ & $\begin{array}{l}\text { For individuals from } 60 \text { to } 80 \text {, the abstinence is } \\
\text { linked with a higher risk of dementia related death, } \\
\text { while light alcohol drinking reduces risk (HR: } 1.33 \text {, } \\
\qquad 95 \% \mathrm{CI}=1.14-1.56) \text {. }\end{array}$ & Not discussed \\
\hline $\begin{array}{c}\text { Dikalov et al. } \\
\text { [117] }\end{array}$ & Tobacco smoking & $\begin{array}{c}\text { Tobacco smoking enhances hypertension, induces } \\
\text { mitochondrial oxidative stress, and enhance } \\
\text { endothelial disfunction }\end{array}$ & $\begin{array}{l}\text { Mitochondria-targeted } \\
\text { interventions may } \\
\text { help to improve } \\
\text { changes caused by } \\
\text { smoking }\end{array}$ \\
\hline Batty et al. [118] & Tobacco smoking & $\begin{array}{c}\text { Smoking increases risk of dementia => Plasma } \\
\text { cotinine (HR:1.29, 95\% CI = 1.05-1.59) and salivary } \\
\text { cotinine (HR:1.10,95\% CI =0.89-1.36) }\end{array}$ & Not discussed \\
\hline Choi et al. [119] & Tobacco smoking & $\begin{array}{c}\text { Risk of dementia for no smokers (HR:0.86, } 95 \% \text { CI } \\
=0.75-0.99) \text { and quit smoking long-time ago }(\mathrm{HR} \text { : } \\
0.81 ; 95 \% \mathrm{CI}=0.71-0.91)=>\text { quit smoking reduces } \\
\text { risk of dementia }\end{array}$ & $\begin{array}{l}\text { Help and encourage } \\
\text { smokers to quit } \\
\text { tobacco smoking }\end{array}$ \\
\hline
\end{tabular}

OR-Odds ratio; HR_-Hazard ratio; CI—Confidence interval; RR—Relative risk; AD—Alzheimer's disease.

In contrast to alcohol misuse, where the findings on the effect of alcohol consumption levels on the risk of dementia are inconsistent, smokers always have a higher risk of dementia in later life (see Table 5). Cigarette smoking produces oxidative stress in the brain $[117,120]$ that in time can cause vascular disfunction and lead to dementia. Smokers are generally more vulnerable to cardiovascular events and vascular dementia than non-smoking individuals. Surprisingly, no strong evidence supporting a connection between passive smoking and an increased risk of dementia has been yet found [118]. On the other hand, the risk of dementia is reduced once an individual quits smoking for a prolonged time, therefore, it is of great importance to public health to help smokers quit smoking [119].

\subsection{Relationship between Sleep Disorders and Dementia (Alzheimer's Disease)}

Individuals with vascular dementia, AD and other types of dementia are often diagnosed with sleeping pattern problems. Many studies, which findings are given in Table 6, have proposed an association between sleep problems, especially, for obstructive sleep apnea patients and a higher risk of dementia [56,121-123]. Some researchers believe that obstructive sleep apnea may even start the AD neuropathological process [124]. In general, sleep problems cause changes in A $\beta$ peptide and $t$-tau protein levels, and probably may even complicate the removal of neurotoxic A $\beta$ peptide [118]. Importantly, a connection between sleep behavior disorders and dementia is currently supported by the findings of a long-term follow-up study [125]. Unfortunately, results supporting the protective effect of sleep medication on a reduced risk of dementia are yet inconsistent [126]. For example, the frequent use of sleep medication in midlife may increase the risk of dementia. In contrast, treatment of obstructive sleep apnea by continuous positive airway pressure enables one to reduce sleep fragmentation and, afterward, helps stabilize levels of $\mathrm{A} \beta$ peptide $t$-tau protein as well as improve the cognitive functions of individuals diagnosed with obstructive sleep apnea [127]. Some studies have also suggested to use of cannabinoids in the treatment of dementia [128]. However, studies focusing on the effectiveness of cannabinoids and/or sleep medication for the treatment of dementia are currently under extensive investigation and the results of these clinical studies are still not available. 
Table 6. Studies associating sleep disorder with dementia and Alzheimer's disease.

\begin{tabular}{cccc}
\hline Study & Factor & Effect/Findings & Interventions \\
\hline Elias et al. [121] & $\begin{array}{c}\text { Sleep } \\
\text { disorder-(OSA) }\end{array}$ & $\begin{array}{c}\text { OSA causes an increased amyloid } \beta \text {-protein } \\
\text { deposition and increases risk of AD. BMI \& APOE } \\
\varepsilon 4 \text { can moderate } \beta \text {-amyloid deposition. }\end{array}$ & Not discussed \\
\hline $\begin{array}{c}\text { Przybylska-Kuć } \\
\text { et al. [122] }\end{array}$ & $\begin{array}{c}\text { Sleep } \\
\text { disorder-(OSA) }\end{array}$ & $\begin{array}{c}\text { A } \beta 40 \text { level is much higher in patients with severe } \\
\text { OSA than those with moderate OSA or no OSA, } \\
\text { Higher A } \beta 40 \text { may lead to AD }\end{array}$ & Not discussed \\
\hline Hahn et al. [123] & $\begin{array}{c}\text { Sleep } \\
\text { disorder-(OSA) }\end{array}$ & $\begin{array}{c}\text { Reduced sleep associated with } ~ 75 \% \text { increased risk } \\
\text { of dementia (HR:1.75; 95\% CI = 1.04-2.93) and } \\
\text { doubles risk of AD (HR:2.01; 95\% CI = 1.12-3.61) }\end{array}$ & Not discussed \\
\hline Liguori et al. & $\begin{array}{c}\text { Sleep } \\
\text { [124] }\end{array}$ & $\begin{array}{c}\text { Sleep disruption and intermittent hypoxia induce } \\
\text { orexinergic system and cerebral } \beta \text {-amyloid } \\
\text { metabolism dysregulation and alteration in CFS } \\
\text { orexin level, it supports hypothesis that OSA may } \\
\text { start AD neuropathological processes. }\end{array}$ & Not discussed \\
\hline Marchand et al. & $\begin{array}{c}\text { Sleep disorder - } \\
\text { REM sleep } \\
\text { [125] }\end{array}$ & $\begin{array}{c}\text { REM sleep behavior disorder causes cognitive } \\
\text { decline and is associated with neurodegenerative } \\
\text { disorders that may lead to dementia }\end{array}$ & Not discussed. \\
\hline OSA-Obstructive sleep apnea; HR-Hazard ratio; CI-Confidence interval; AD-Alzheimer's disease.
\end{tabular}

\section{Future Possible Research Directions and Trends in the Treatment of Dementia and Alzheimer's Disease Using Single-Domain and Multi-Domain Interventions}

The vulnerability of individuals to cognitive decline and an increased risk of dementia or AD is complex. It depends, in addition to age and genetic predisposition (non-modifiable risk factors), on several protective and potentially modifiable risk factors. Hence, it is generally accepted by psychologists and psychiatrists that the cognitive functions can be maintained and the risk for cognitive decline and, correspondingly, the development of later life dementia and AD can be notably reduced by interventions targeting individuals' risk factors [21]. These interventions may target one given dementia risk factor, often referred as the "single-domain" interventions, or multiple risk factors of dementia, also known as "multidomain" interventions. Despite the fact that a large number of potential single-domain interventions were already identified and we also briefly discussed some of the possible interventions in previous section, there is still a lack of supporting evidence from randomized control trials for the effectiveness of these interventions. We also emphasize here that the results of recent long-term follow-up studies support the hypothesis that the prodromes of dementia may possibly start more than decade before any clinical symptoms can be observed [46-48]. The short duration of treatment (trials) and small sample size are among the main limitations of the most published randomized control trials [129]. Other limitations can even include a not well-defined cognitive outcome. We only note that many researchers are using different measures, sample sizes and terminologies, complicating the interpretation and generalization of their findings. As a result, existing trial studies usually do not provide sufficient information on what intensity of intervention targeting a given risk factor is needed to preserve cognitive function. We can, therefore, conclude that a possible future research direction could be targeting the relationship between the intensity of a given intervention and cognitive functioning. Nevertheless, before any systematic trials can be carried out, a precise terminology should be established [8]. Then, the large sample size and a long follow-up period that might go back even far beyond the midlife with clearly defined trial conditions would be required to find the relationship(s) between various interventions and a possibly reduced risk of dementia and AD.

The neuropathological processes that may cause the cognitive decline and lead to dementia and $\mathrm{AD}$ depend on the genetic predisposition, age and the combination of multiple possibly modifiable risk factors (discussions on known possibly modifiable risk factors are given in Sections 3 and 4) [130]. We remind the reader that, for instance, midlife obesity is often associated with hypertension and diabetes mellitus. These three possibly modifiable risk factors can cause an accumulation of neurotoxic 
peptides and oxidative stress level changes in the brain that in time may result in cognitive impairment and dementia $[78,81,89]$. Similarly, the higher risk of dementia in the elderly individuals with various comorbid cardiometabolic diseases such as diabetes mellitus or stroke can be moderated by social engagement and physical activities [131]. The effects of (non-)modifiable risk and protective factors are also age- and gender-dependent. As an example, we can consider hypertension, which during the midlife increases the risk of later life dementia but hypertension developed in late-life may have the protective effect [92]. Since multiple risk and protective factors usually occur together and their effect on the individual's cognitive functions may be gender dependent and varies in time, therefore single-domain interventions might not be sufficient to maintain cognitive functioning and delay the prodromes of dementia for a majority of the so-called "at-risk" individuals. Multidomain interventions targeting multiple risk factors may be of importance to preserve or improve individuals' cognition and reduce the risk for development or delay the prodromes of dementia [132]. One of the earliest trials performed on a large sample size comprised of 1260 individuals provided evidence supporting the effectiveness of multidomain interventions in the prevention of dementia for at-risk individuals [133]. In contrast, some other earlier multidomain trials did not meet the expected outcome criteria (a decrease in the overall number of dementia cases) but they provide evidence, even though still limited, supporting improvements for individuals with untreated hypertension or complications with the removal of amyloid peptide from the brain $[134,135]$. Future multidomain interventions should, therefore account for the differences and heterogeneity in the risk factors of individuals, culture, and ethnical differences, etc. Then, each group of people with the similar risk factors at a given time-period, culture background and the social engagement should be treated by multidomain interventions specially designed for a given group of individuals [136]. The electronic health (eHealth) and mobile health (mHealth) solutions can also help design more efficient multidomain trials and provide support for "at-risk" elderly individuals [137]. Personalized target multidomain interventions may be, therefore, considered as one of the future trends in prevention and treatment of dementia.

Based on the evidence discussed in Sections 3 and 4, we may also hypothesize that to understand the underlying mechanisms of dementia (and AD) neuropathology would probably require tracing individuals' multiple risk and protective factors back to at least their midlife or even to early life (e.g., individuals with higher idea density scores in early life were found to not have cognitive deficits in later life [138]). In addition, these future studies may also need to link changes in body fluids during an individual's lifetime and subject to various risk factors (i.e., each risk and protective factor may affect individual differently in early-, mid- or later life). We also envisage that changes in body fluids in early to midlife may be associated with different roles of individual risk factors and, correspondingly, with the risk for development of dementia and $\mathrm{AD}$ in later life. This hypothesis, however, requires future systematic investigation, that is, multiple observational studies and clinical trials to be carried out.

\section{Limitations}

The main limitation of this literature review is the lack of a systematic analysis of the published literature review (i.e., we include the latest studies that are rigorous, with results clearly supported by data, and measures that are well established. We excluded non-English studies, duplicate results, studies where data are not clearly explained, or the hypotheses are not supported by evidence/data). Details of the inclusion and exclusion criteria are given in Section 2. However, dementia and AD are heterogeneous disorders caused by a combination of the multiple (non-)modifiable factors (e.g., late life depression, hypertension, obesity, social engagement, etc.). Hence, to understand the underlying mechanisms of dementia and $\mathrm{AD}$ pathogeneses requires their multifactorial nature represented by the combination of the multiple factors to be considered. We therefore believe that it is of great value to the clinician and public health audience to provide a literature review focusing on the latest understanding of the roles of the individual identified (non-)modifiable risk factors in the development of dementia and $\mathrm{AD}$, rather than focusing on any particular risk factor. 


\section{Conclusions}

This review presents a literature overview of the latest findings associating known (non-)modifiable risk factors with the risk for development of dementia and AD. The advantages, drawbacks and limitations of possible interventions have been also discussed. Furthermore, possible future directions in research and treatment of dementia are highlighted. Overall, this review accounts for the latest suggestions, hypothesis, and findings in the fast-growing field of dementia and AD that can be used to design the future strategies needed for prevention and treatment of both dementia and AD.

Author Contributions: Conceptualization, C.-Y.K., I.S. and T.N.; investigations, C.-Y.K. and I.S.; resources I.S.; writing-original draft C.-Y.K.; writing-review and editing I.S.; funding acquisition C.-Y.K. and I.S. All authors have read and agreed to the published version of the manuscript.

Funding: This work was supported by the research project of Drážní revize s.r.o. and by Operational Programme Research, Development and Education financed by European Structural and Investment Funds and the Czech Ministry of Education, Youth and Sports (Project No. SOLID21 - CZ.02.1.01/0.0/0.0/16_019/0000760).

Conflicts of Interest: The authors declare no conflict of interest.

\section{References}

1. Steenman, M.; Lande, G. Cardiac aging and heart disease in humans. Biophys. Rev. 2017, 9, 131-137. [CrossRef]

2. Weir, H.K.; Anderson, R.N.; Coleman-King, S.M.; Soman, A.; Thompson, T.D.; Hong, Y.; Moller, B.; Leadbetter, S. Heart disease and cancer deaths-Trends and projections in the United States, 1969-2020. Prev. Chronic. Dis. 2016, 13, E157. [CrossRef] [PubMed]

3. Laidlaw, K.; Pachana, N.A. Aging, mental health, and demographic change: Challenges for psychotherapists. Prof. Psychol. Res. Pract. 2009, 40, 601-608. [CrossRef]

4. Mirowski, J.; Ross, C.E. Age and depression. J. Health Soc. Behav. 1992, 33, 187-205. [CrossRef]

5. Vink, D.; Aartsen, M.J.; Comijs, H.C.; Heymans, M.W.; Penninx, B.W.J.H.; Stek, M.L.; Deeg, D.J.H.; Beekman, A.T.F. Onset of anxiety and depression in the aging population: Comparison of risk factors in a 9-year prospective study. Am. J. Geriatr. Psychiatry 2009, 17, 642-652. [CrossRef] [PubMed]

6. Djernes, J.K. Prevalence and predictors of depression in populations of elderly: A review. Acta Psychiatr. Scand. 2006, 113, 372-387. [CrossRef]

7. Diniz, B.S.; Butters, M.A.; Albert, S.M.; Dew, M.A.; Reynolds, C.F. Late-life depression and risk of vascular dementia and Alzheimer's disease: Systematic review and meta-analysis of community-based cohort studies. Br. J. Psychiatry 2013, 202, 329-335. [CrossRef]

8. Steffens, D.S. Late-life depression and the prodromes of dementia. JAMA Psychiatry 2017, 74, 673-674. [CrossRef]

9. Kokmen, E.; Beard, C.M.; Chandra, V.; Offord, K.P.; Schoenberg, B.S.; Ballard, D.J. Critical risk factors for Alzheimer's disease: A population-based case-control study. Neurology 1991, 41, 1393-1397. [CrossRef]

10. Herbert, J.; Lucassen, P.J. Depression as a risk factor for Alzheimer's disease: Genes, steroids, cytokines and neurogenesis-What do we need to know? Front. Neuroendocrinol. 2016, 41, 153-171. [CrossRef]

11. Alzheimer's Association. 2020 Alzheimer's Disease Facts and Figures. Available online: https://www.alz. org/alzheimers-dementia/facts-figures (accessed on 1 January 2020).

12. Alzheimer's Disease International. World Alzheimer's report 2019 Attitudes to Dementia. Available online: https://www.alz.co.uk/research/world-report-2019 (accessed on 3 September 2019).

13. Stampfer, M.J. Cardiovascular disease and Alzheimer's disease: Common links. J. Intern. Med. 2006, 260, 211-223. [CrossRef]

14. de Brujin, R.F.A.G.; Ikram, M.A. Cardiovascular risk factors and future risk of Alzheimer's disease. BMC Med. 2014, 12, 130. [CrossRef] [PubMed]

15. Profenno, L.A.; Porsteinsson, A.P.; Fareone, V. Meta-analysis of Alzheimer's disease risk with obesity, diabetes, and related disorders. Biol. Psychiatry 2010, 67, 505-512. [CrossRef] [PubMed]

16. Livingston, G.; Sommerlad, A.; Orgeta, V.; Costafreda, S.G.; Huntley, J.; Ames, D.; Ballard, C.; Banerjee, S.; Burns, A.; Cohen-Mansfield, J.; et al. Dementia prevention, intervention, and care. Lancet 2017, 390, 2673-2734. [CrossRef] 
17. Craik, F.I.M.; Bialystok, E.; Freedman, M. Delaying the onset of Alzheimer disease. Neurology 2010, 75, $1725-1729$. [CrossRef]

18. Rasmussen, J.; Langerman, H. Alzheimer's disease-Why we need early stage diagnosis. Degener. Neurol. Neuromuscul. Dis. 2019, 9, 123-130. [CrossRef] [PubMed]

19. Brookmeyer, R.; Abdalla, N.; Kawas, C.H.; Corrada, M.M. Forecasting the prevalence of preclinical and clinical Alzheimer's disease in the United States. Alzheimers Dement. 2018, 14, 121-129. [CrossRef] [PubMed]

20. Almeida, O.P.; Hankey, G.J.; Yeap, B.B.; Golledge, J.; Flicker, L. Depression as a modifiable factor to decrease the risk of dementia. Transl. Psychiatry 2017, 7, e1117. [CrossRef]

21. Kivipelto, M.; Mangialasche, F.; Ngandu, T. Lifestyle interventions to prevent cognitive impairment, dementia and Alzheimer's disease. Nat. Rev. Neurol. 2018, 14, 653-666. [CrossRef]

22. Mortimer, J.A.; Stern, Y. Physical exercise and activity may be important in reducing dementia risk at any age. Neurology 2019, 92, 1-2. [CrossRef]

23. Bott, N.T.; Hall, A.; Madero, E.N.; Glenn, J.M.; Fuseya, N.; Gills, J.L.; Gray, M. Face-to-face and digital multidomain lifestyle interventions to enhance cognitive reserve and reduce risk of Alzheimer's disease and related dementias: A review of completed and prospective studies. Nutrients 2019, 11, 2258. [CrossRef] [PubMed]

24. Munn, Z.; Peters, M.D.J.; Stern, C.; Tufanaru, C.; McArthur, A.; Aromataris, E. Systematic review or scoping review? Guidance for authors when choosing between a systematic or scoping review approach. BMC Med. Res. Methodol. 2018, 18, 143. [CrossRef] [PubMed]

25. Tricco, A.C.; Lillie, E.; Zarin, W.; O’Brien, K.K.; Levac, D.; Moher, D.; Peters, M.D.J.; Horsley, T.; Weeks, L.; Hempel, S.; et al. PRISMA extension for scoping reviews (PRISMA-ScR): Checklist and explanation. Ann. Intern. Med. 2018, 169, 467-473. [CrossRef]

26. van Wanrooij, L.L.; Borsboom, D.; Moll van Charante, E.P.; van Gool, W.A. A network approach on the relation between apathy and depression symptoms with dementia and functional disability. Int. Psychogeriatr. 2019, 31, 1655-1663. [CrossRef]

27. Balsis, S.; Carpenter, B.D.; Storandt, M. Personality change precedes clinical diagnosis of dementia of the Alzheimer's type. J. Gerontol. B Psychol. Sci. Soc. Sci. 2005, 60, P98-P101. [CrossRef] [PubMed]

28. Reise, S.P.; Wallet, N.G. Item response theory and clinical measurement. Annu. Rev. Clin. Psychol. 2009, 5, $27-48$. [CrossRef] [PubMed]

29. Barnes, D.E.; Alexopoulos, G.S.; Lopez, O.L.; Williamson, J.D.; Yaffe, K. Depressive symptoms, vascular disease, and mild cognitive impairment. Arch. Gen. Psychiatry 2006, 63, 273-279. [CrossRef] [PubMed]

30. Johnson, D.K.; Watts, A.S.; Chapin, B.A.; Anderson, R.; Burns, J.M. Neuropsychiatric profiles in dementia. Alzheimer Dis. Assoc. Disord. 2011, 25, 326-332. [CrossRef]

31. Leoutsakos, J.-M.S.; Forrester, S.N.; Corcoran, C.D.; Norton, M.C.; Rabins, P.V.; Steinberg, M.I.; Tschanz, J.T.; Lyketsos, C.G. Latent classes of course in Alzheimer's disease and predictors: The Cache county dementia progression study. Int. J. Geriatr. Psychiatry 2015, 30, 824-832. [CrossRef] [PubMed]

32. Gatz, J.L.; Tyas, S.L.; John, P.; Montgomery, P. Do depressive symptoms predict Alzheimer's disease and dementia? J. Gerontol. A Biol. Sci. Med. Sci. 2005, 60, 744-747. [CrossRef]

33. Olaya, B.; Moneta, M.V.; Miret, M.; Ayuso-Mateos, J.L.; Haro, J.M. Course of depression and cognitive decline at 3-years follow-up: The role of age of onset. Psychol. Aging 2019, 34, 475-485. [CrossRef] [PubMed]

34. Geerlings, M.I.; Bouter, L.M.; Schoevers, R.A.; Beekman, A.T.F.; Jonker, C.; Deeg, D.J.J.; Tilburg, W.V.; Ader, H.J.; Schmand, B. Depression and risk of cognitive decline and Alzheimer's disease: Results of two prospective community-based studies in The Netherlands. Br. J. Psychiatry 2000, 176, 568-575. [CrossRef] [PubMed]

35. Xia, M.; Yang, L.; Sun, G.; Qi, S.; Li, B. Mechanism of depression as a risk factor in the development of Alzheimer's disease: The function of AQP4 and the glymphatic system. Psychopharmacology 2017, 234, 365-379. [CrossRef] [PubMed]

36. Burke, S.L.; Cadet, T.; Alcide, A.; O’Driscoll, J.; Maramaldi, P. Psychosocial risk factors and Alzheimer's disease: The associative effect of depression, sleep disturbance, and anxiety. Aging Ment. Health 2017, 22, 1-8. [CrossRef] [PubMed]

37. Migliorelli, R.; Teson, A.; Sabe, L.; Petracchi, M.; Leiguarda, R.; Starkstein, S.E. Prevalence and correlates of dysthymia and major depression among patients with Alzheimer's disease. Am. J. Psychiatry 1995, 152, $37-44$. [CrossRef] [PubMed] 
38. Barca, M.L.; Persson, K.; Eldholm, R.; Benth, J.S.; Kersten, H. Trajectories of depressive symptoms and their relationship to the progression of dementia. J. Affect. Disord. 2017, 222, 146-152. [CrossRef]

39. Enache, D.; Winblad, B.; Aarsland, D. Depression in dementia: Epidemiology, mechanisms, and treatment. Curr. Opin. Psychiatry 2011, 24, 461-472. [CrossRef]

40. Kaup, A.R.; Byers, A.L.; Falvey, C.; Simonsick, E.M.; Satterfield, S. Trajectories of depressive symptoms in older adults and risk of dementia. JAMA Psychiatry 2016, 73, 525-531. [CrossRef]

41. Ownby, R.L.; Crocco, E.; Acevedo, A.; John, V.; Loewenstein, D. Depression and risk for Alzheimer's disease: Systematic review, Meta-analysis, and Meta-regression analysis. Arch. Gen. Psychiatry 2006, 63, 530-538. [CrossRef]

42. Tapainen, V.; Hartikainen, S.; Taipale, H.; Tiihonen, J.; Tolppanen, A.-M. Hospital-treated mental and behavioral disorders and risk of Alzheimer's disease: A nationwide nested case-control study. Eur. Psychiatry 2017, 43, 92-98. [CrossRef]

43. Becker, J.T.; Chang, Y.F.; Lopez, O.L.; Dew, M.A.; Sweet, R.A.; Barnes, D.; Yaffe, K.; Young, K.; Kuller, L.; Reynolds III, C.F. Depressed mood is not a risk factor for incident dementia in a community-based cohort. Am. J. Geriatr. Psychiatry 2009, 17, 653-663. [CrossRef]

44. Brommelhoff, J.A. Depression as a risk factor or prodromal feature for dementia? Findings in a population-based sample of Swedish twins. Psychol. Aging 2009, 24, 373-384. [CrossRef]

45. Valkanova, V.; Ebmeier, K.P.; Allan, C.L. Depression is linked to dementia in older adults. Practioner 2017, 261, 11-15. [CrossRef]

46. Saczynski, J.S.; Beiser, A.; Seshadri-Auerbach, S.; Wolf, P.A.; Au, R. Depressive symptoms and risk of dementia. Neurology 2010, 75, 35-41. [CrossRef] [PubMed]

47. Li, G.; Wang, L.Y.; Shofer, J.B.; Thompson, M.L.; Peskind, E.R.; McCormick, W.; Bowen, J.D.; Crane, P.K.; Larson, E.B. Temporal relationship between depression and dementia: Findings from a large community-based 15-year follow-up study. Arch. Gen. Psychiatry 2011, 68, 970-977. [CrossRef] [PubMed]

48. Amieva, H.; Goff, M.L.; Millet, X.; Orgogozo, J.M.; Pérès, K.; Barberger-Gateau, P.; Jacqmin-Gadda, H.; Dartigues, J.F. Prodromal Alzheimer's disease: Successive emergence of the clinical symptoms. Ann. Neurol. 2008, 64, 492-498. [CrossRef]

49. Singh-Manoux, A.; Dugravot, A.; Fournier, A.; Abell, J.; Ebmeier, K.; Kivimaki, M.; Sabia, S. Trajectories of depressive symptoms before diagnosis of dementia: A 28-year follow-up study. JAMA Psychiatry 2017, 74, 712-718. [CrossRef]

50. Pierce, A.L.; Kawas, C.H. Dementia in the oldest old: Beyond the Alzheimer's disease. PLoS Med. 2017, 14, e1002263. [CrossRef]

51. Ritchie, K.; Lovestone, S. The dementias. Lancet 2002, 360, 1759-1766. [CrossRef]

52. Kivipelto, M.; Rovio, S.; Ngandu, T.; Kåreholt, I.; Eskelinen, M.; Winblad, B.; Hachinsku, V.; Cedazo-Minguez, A.; Soininen, H.; Tuomilehto, J.; et al. Apolipoprotein E 4 magnifies lifestyle risks for dementia: A population-based study. J. Cell. Mol. Med. 2008, 12, 2762-2771. [CrossRef]

53. Solomon, A.; Turunen, H.; Ngandu, T.; Peltonen, M.; Levälahti, E.; Helisalmi, S.; Antikainen, R.; Backman, L.; Hanninen, T.; Jula, A. Effect of the apolipoprotein E genotype on cognitive change during a multidomain lifestyle intervention: A subgroup analysis of a randomized clinical trial. JAMA Neurol. 2018, 75, 462-470. [CrossRef] [PubMed]

54. van der Lee, S.J.; Wolters, F.; Ikram, M.K.; Hofman, A.; Ikram, M.A.; Amin, N.; Dujin, C.M.V. The effect of APOE and other common genetic variants on the onset of Alzheimer's disease and dementia: A community-based cohort study. Lancet Neurol. 2018, 17, 434-444. [CrossRef]

55. Licher, S.; Ahmad, S.; Karamujić-Čomić, H.; Voortman, T.; Leeing, M.J.G.; Ikram, M.A.; Ikram, M.K. Genetic predisposition, modifiable-risk-factor profile and long-term dementia risk in the general population. Nat. Med. 2019, 25, 1364-1369. [CrossRef]

56. Burke, S.L.; Maramaldi, P.; Cadet, T.; Kukull, W. Association between depression, sleep disturbance, and apolipoprotein E in the development of Alzheimer's disease: Dementia. Int. Psychogeriatr. 2016, 28, 1409-1424. [CrossRef]

57. Rasmussen, K.L.; Tybjaer-Hansen, A.; Nordestgaard, B.G.; Frikke-Schmidt, R. Plasma apolipoprotein E levels and risk of dementia: A Mendelian randomization study of 106,562 individuals. Alzheimers Dement. 2018, 14, 71-80. [CrossRef] [PubMed] 
58. Johnson, E.C.B.; Dammer, E.B.; Duong, D.M.; Ping, L.; Zhou, M.; Yin, L.; Higginbotha, L.A.; Guajardo, A.; White, B.; Troncoso, J.C.; et al. Large-scale proteomic analysis of Alzheimer's disease brain and cerebrospinal fluid reveals early changes in energy metabolism associated with microglia and astrocyte activation. Nat. Med. 2020, 26, 769-780. [CrossRef]

59. Farrer, L.A.; Cupples, L.A.; Haines, J.L. Effects of age, sex, the ethnicity on association between Apolipoprotein E genotype and Alzheimer disease. JAMA 1997, 278, 1349-1356. [CrossRef]

60. Waring, S.C.; Rocca, W.A.; Petersen, R.C.; O’Brein, P.C.; Tangalos, E.G.; Kokmen, E. Postmenopausal estrogen replacement therapy and risk of AD: A population-based study. Neurology 1999, 52, 956-970. [CrossRef]

61. Imtiaz, B.; Tuppurainen, M.; Rikkonen, T.; Kivipelto, M.; Soininen, H.; Kroger, H.; Tolppanen, A.-M. Postmenopausal hormone therapy and Alzheimer disease: A prospective cohort study. Neurology 2017, 88, 1062-1068. [CrossRef]

62. Savolainen-Peltonen, H.; Rahkola-Soisalo, P.; Hoti, F.; Vattulainen, P.; Gissler, M.; Ylikorkala, O.; Mikkola, T.S. Use of postmenopausal hormone therapy and risk of Alzheimer's disease in Finland: Nationwide case-control study. BMJ 2019, 364, 1665. [CrossRef]

63. Shao, H.; Breitner, J.C.S.; Whitmer, R.A.; Wang, J.; Hayden, K.; Wengreen, H.; Corcoran, C.; Tschanz, J.; Norton, M.; Munger, R.; et al. Hormone therapy and Alzheimer disease dementia. Neurology 2012, 79, 1846-1852. [CrossRef] [PubMed]

64. Lv, W.; Du, N.; Liu, Y.; Fan, X.; Wang, Y.; Jia, X.; Hou, X.; Wang, B. Low testosterone level and risk of Alzheimer's disease in the elderly men: Systematic review and meta-analysis. Mol. Neurobiol. 2016, 53, 2679-2684. [CrossRef]

65. Ford, A.H.; Yeap, B.B.; Flicker, L.; Hankey, G.J.; Chubb, S.A.P.; Golledge, J.; Almeida, O.P. Sex hormones and incident dementia in older men: The health in men study. Psychoneuroendocrinology 2018, 98, 139-147. [CrossRef]

66. Carcaillon, L.; Brailly-Tabard, S.; Ancelin, M.-L.; Tzourio, C.; Foubert-Samier, A.; Dartigues, J.-F.; Guiochon-Mantel, A.; Scarabin, P.-Y. Low testosterone and the risk of dementia in elderly men: Impact of age and education. Alzheimers Dement. 2013, 10, S306-S310. [CrossRef]

67. Alivisatos, A.P.; Chun, M.; Church, G.M.; Greenspan, R.J.; Roukes, M.L.; Yuste, R. The Brain Activity Map Project and the Challenge of Functional Connectomics. Neuron 2012, 74, 970-974. [CrossRef]

68. Stachiv, I.; Gan, L.; Kuo, C.-Y.; Sittner, P.; Sevecek, O. Mass Spectrometry of Heavy Analytes and Large Biological Aggregates by Monitoring Changes in the Quality Factor of Nanomechanical Resonators in Air. ACS Sens. 2020, 5, 2128-2135. [CrossRef]

69. Winblad, B.; Amouyel, P.; Andrieu, S.; Ballard, C.; Brayne, C.; Brodaty, H.; Cedazo-Minguez, A.; Dubois, B.; Edvardsson, D.; Feldman, H.; et al. Defeating Alzheimer's disease and other dementias: A priority for European science and society. Lancet Neurol. 2016, 15, 455-532. [CrossRef]

70. Pike, C.J. Sex and the development of Alzheimer's disease. J. Neurosci. Res. 2017, 95, 671-680. [CrossRef] [PubMed]

71. Wahjoepramono, E.J.; Asih, P.R.; Aniwiyanti, V.; Taddei, K.; Dhaliwal, S.S.; Fuller, S.J.; Foster, J.; Carruthers, M.; Verdile, G.; Sohrabi, R.H.; et al. The effects of testosterone supplementation on cognitive functioning in older men. CNS Neurol. Disord. Drug Targets 2016, 15, 337-343. [CrossRef]

72. Bennett, S.; Thomas, A.J. Depression and dementia: Cause, consequence or coincidence? Maturitas 2014, 79, 184-190. [CrossRef]

73. Gimson, A.; Schlosser, M.; Huntley, J.D.; Marchant, N.L. Support for midlife anxiety diagnosis as an independent risk factor for dementia: A systematic review. BMJ Open 2018, 8, e019399. [CrossRef]

74. Shalev, D.; Arbuckle, M.R. Metabolism and memory: Obesity, diabetes and dementia. Biol. Psychiatry 2017, 82, e81-e83. [CrossRef]

75. Xu, W.L.; Atti, A.R.; Gatz, M.; Pedersen, N.L.; Johansson, B.; Fratiglioni, L. Midlife overweight and obesity increase late-life depression risk: A population-based twin study. Neurology 2011, 76, 1568-1574. [CrossRef]

76. Albanese, E.; Launer, L.J.; Egger, M.; Prince, M.J.; Giannakopoulos, P.; Wolters, J.F.; Egan, K. Body mass index in midlife and dementia: Systematic review and meta-regression analysis of 589,649 men and women followed in longitudinal studies. Alzheimers Dement. 2017, 8, 165-178. [CrossRef]

77. Kivimaki, M.; Luukkonen, R.; Batty, G.D.; Ferrie, J.E.; Pentti, J.; Nyberg, S.T.; Shipley, M.J.; Alfredsson, L.; Fransson, E.I.; Goldberg, M.; et al. Body mass index and risk of dementia: Analysis of individual-level data from 1.3 million individuals. Alzheimers Dement. 2018, 14, 601-609. [CrossRef] 
78. Floud, S.; Simpson, R.F.; Balkwill, A.; Brown, A.; Goodill, A.; Gallacher, J.; Sudlow, C.; Harris, P.; Hofman, A.; Parish, S.; et al. Body mass index, diet, physical inactivity, and the incidence of dementia in 1 million UK women. Neurology 2020, 94, e123-e132. [CrossRef] [PubMed]

79. Lazar, M.A. How obesity causes diabetes: Not a tall tale. Science 2005, 307, 373-375. [CrossRef] [PubMed]

80. Gonzales-Reyes, R.E.; Aliev, G.; Avila-Rodrigues, M.; Barreto, G.E. Alterations in glucose metabolism on cognition: A possible link between diabetes and dementia. Curr. Pharm. Des. 2016, 22, 812-818. [CrossRef]

81. Fan, Y.-C.; Hsu, J.-L.; Tung, H.-Y.; Chou, C.-C.; Bai, C.-H. Increased dementia risk predominantly in diabetes mellitus rather than in hypertension or hyperlipidemia: A population-based cohort study. Alzheimers Res. Ther. 2017, 9, 7. [CrossRef]

82. Avgerinos, K.L.; Kalaitzidas, G.; Malli, A.; Kalaitzoglou, D.; Myserlis, P.G.; Lioutas, V.-A. Internasal insulin in Alzheimer's dementia or mild cognitive impairment: A systematic review. J. Neurol. 2018, 265, 1497-1510. [CrossRef] [PubMed]

83. Emdin, C.A.; Rothwell, H.P.M.; Salimi-Khorshidi, F.G.; Kiran, D.A.; Conrad, N.; Callender, T.; Mehta, Z.; Pendlebury, S.T.; Anderson, S.G.; Mohseni, H.; et al. Blood pressure and risk of vascular dementia: Evidence from 4.3 million adults and a cohort study of TIA and stroke. Stroke 2016, 47, 1429-1435. [CrossRef]

84. Nagai, M.; Hoshide, S.; Kairo, K. Hypertension and dementia. Am. J. Hypertens. 2010, 23, 116-124. [CrossRef]

85. Janelidze, S. Plasma $\beta$-amyloid in Alzheimer's disease and vascular disease. Sci. Rep. 2016, 6, 26801. [CrossRef]

86. Walker, K.A.; Sharrett, A.R.; Wu, A.; Schneider, A.L.C.; Albert, M.; Lutsey, P.L.; Bandeen-Roche, K.; Coresh, J.; Gross, A.L.; Windham, B.G.; et al. Association of midlife to late-life blood pressure patterns with incident dementia. JAMA 2019, 322, 535-545. [CrossRef]

87. Corrada, M.M.; Hayden, K.M.; Paganini-Hill, A.; Bullain, S.S.; de Moss, J.; Aguirre, C.; Brookmeyer, R.; Kawas, H.C. Age of onset of hypertension and risk of dementia in the oldest-old: The 90+ study. Alzheimers Dement. 2017, 13, 103-110. [CrossRef]

88. Gilsanz, P.; Mayeda, E.R.; Glymour, M.M.; Quesenberry, C.P.; Mungas, D.M.; DeCarli, C.; Dean, A.; Whitmer, A.R. Female sex, early-onset hypertension, and risk of dementia. Neurology 2017, 89, 1-8. [CrossRef]

89. Murray, M.D.; Hendrie, H.C.; Lane, K.A.; Zheng, M.; Ambuehl, R.; Li, S.; Unverzagt, W.F.; Callahan, M.C.; Gao, S. Antihypertensive medication and dementia risk in older adult African Americans with hypertension: A prospective cohort study. J. Gen. Intern. Med. 2018, 33, 455-462. [CrossRef]

90. Smith, E.E.; Schneider, J.A.; Wardlaw, J.M.; Greenberg, S.M. Cerebral microinfarcts: The invisible lesions. Lancet Neurol. 2012, 11, 272-282. [CrossRef]

91. Igase, M.; Kohara, K.; Miki, T. The association between hypertension and dementia in elderly. Int. J. Hypertens. 2012, 2012, 320648. [CrossRef]

92. Iadecola, C. Hypertension and dementia. Hypertension 2014, 64, 3-5. [CrossRef]

93. Turana, Y.; Tengkawan, J.; Chia, Y.C.; Hoshide, S.; Shin, J.; Chen, C.-H.; Buranakitjaroen, P.; Nailes, J.; Park, S.; Siddique, S.; et al. Hypertension and dementia: A comprehensive review from the HOPE Asia network. J. Clin. Hypertens. 2019, 21, 1091-1098. [CrossRef]

94. Perrotta, M.; Lembo, G.; Carnevale, D. Hypertension and dementia: Epidemiological and experimental evidence revealing a detrimental relationship. Int. J. Mol. Sci. 2016, 17, 347. [CrossRef]

95. Skoog, I.; Börjesson-Hanson, A.; Kern, S.; Johansson, L.; Falk, H.; Sigstrom, R.; Ostling, S. Decreasing prevalence of dementia in 85-years olds examined 22 years apart: The influence of education and stroke. Sci. Rep. 2017, 7, 6136. [CrossRef] [PubMed]

96. Xu, W.; Tan, L.; Wang, H.-F.; Tan, M.-S.; Tan, L.; Li, J.-Q.; Zhao, Q.-F.; Yu, J.-T. Education and risk of dementia: Dose-response meta-analysis of prospective cohort studies. Mol. Neurobiol. 2016, 53, 3113-3123. [CrossRef]

97. Nguyen, T.T.; Tchetgen, E.J.T.; Kawachi, I.; Gilman, S.E.; Walter, S.; Liu, Y.S.; Manly, J.J.; Glymour, M.M. Instrumental variable approaches to identifying the casual effect of educational attainment on dementia risk. Ann. Epidemiol. 2016, 26, 71-76. [CrossRef] [PubMed]

98. Then, F.S.; Luck, T.; Angermeyer, M.C.; Riedel-Heller, R.G. Education as protector against dementia, but what exactly do we mean by education? Age Ageing 2016, 45, 523-528. [CrossRef]

99. Matthews, F.E.; Arthur, A.; Barnes, L.; Bond, J.; Jagger, C.; Robinson, L.; Brayne, C. and on behalf of the Medical Research Council Cognitive Function and Ageing Collaboration. A two-decade comparison of prevalence of dementia in individuals aged 65 years and older from three geographical areas of England: Results of the Cognitive Function and Ageing Study I and II. Lancet 2013, 382, 1405-1412. [CrossRef] 
100. Iacono, D.; Zandi, P.; Gross, M.; Markesbery, W.R.; Pletnikova, O.; Rudow, G.; Troncoso, C.J. APOع2 and education in cognitively normal older subjects with high levels of AD pathology at autopsy: Findings from the Nun Study. Oncotarget 2015, 6, 14082-14091. [CrossRef]

101. Wang, H.-X.; Gustafson, D.R.; Kivipelto, M.; Pedersen, N.L.; Skoog, I.; Windblad, B.; Fratiglioni, L. Education halves the risk of dementia due to apolipoprotein $\varepsilon 4$ allele: A collaborative study from Swedish brain power initiative. Neurobiol. Aging 2012, 33, 1007. [CrossRef] [PubMed]

102. Appiah, D.; Baumgartner, R.N. The influence of education and Apoliprotein $\varepsilon 4$ on mortality in community-dwelling elderly men and women. J. Aging Res. 2018, 2018, 6037058. [CrossRef]

103. Zhou, Z.; Wang, P.; Fang, Y. Social engagement and its change are associated with dementia risk among Chinese older adults: A longitudinal study. Sci. Rep. 2018, 8, 1551. [CrossRef]

104. Saito, T.; Murata, C.; Saito, M.; Takeda, T.; Kondo, K. Influence of social relationship domains and their combinations on incident dementia: A prospective cohort study. J. Epidemiol. Community Health 2018, 72, 7-12. [CrossRef] [PubMed]

105. Khondoker, M.; Rafnsson, S.B.; Morris, S.; Orrell, M.; Steptoe, A. Positive and negative experiences of social support and risk of dementia in later life: An investigation using the English longitudinal study of ageing. J. Alzheimers Dis. 2017, 58, 99-108. [CrossRef] [PubMed]

106. Kuiper, J.S.; Zuidersma, M.; Oude-Voshaar, R.C.; Zuidema, S.U.; van den Heuvel, E.R.; Stolk, P.R.; Smidt, N. Social relationships and risk of dementia: A systematic review and meta-analysis of longitudinal cohort studies. Ageing Res. Rev. 2015, 22, 39-57. [CrossRef] [PubMed]

107. Penninkilampi, R.; Casey, A.-N.; Sigh, M.F.; Brodaty, H. The association between social engagement, loneliness, and risk of dementia: A systematic review and meta-analysis. J. Alzheimers Dis. 2018, 66, 1619-1633. [CrossRef] [PubMed]

108. Salinas, J.; Beiser, A.; Himali, J.; Satizabal, C.L.; Aparicio, H.J.; Weinstein, G.; Mateen, J.F.; Berkman, F.L.; Rosand, J.; Seshadri, S. Associations between social relationship measures, serum brain-derived neurotrophic factor, and risk of stroke and dementia. Alzheimers Dement. 2017, 3, 229-237. [CrossRef] [PubMed]

109. Murata, C.; Saito, T.; Saito, M.; Kondo, K. The association between social support and incident dementia: A 10-year follow-up study in Japan. Int. J. Environ. Res. Public Health 2019, 16, 239. [CrossRef]

110. Nithianantharajah, J.; Hannan, A.J. The neurobiology of brain and cognitive reserve: Mental and physical activity as modulators of brain disorders. Prog. Neurobiol. 2009, 89, 369-382. [CrossRef]

111. Bisht, K.; Sharma, K.; Tremblaya, M.-E. Chronic stress as a risk factor for Alzheimer's disease: Roles of microglia-mediated synaptic remodeling, inflammation, and oxidative stress. Neurobiol. Stress 2018, 9, 9-21. [CrossRef]

112. D'Orsi, E.; Xavier, A.J.; Rafnsson, S.B.; Steptoe, A.; Hogervorst, E.; Orrell, M. Is use of the internet in midlife associated with lower dementia incidence? Results from the England longitudinal study of aging. Aging Ment. Health 2018, 22, 1525-1533. [CrossRef]

113. Xu, W.; Wang, H.; Tan, C.; LI, J.; Tan, L.; Yu, J.-T. Alcohol consumption and dementia risk: A dose-response meta-analysis of prospective studies. Eur. J. Epidemiol. 2017, 32, 31-42. [CrossRef] [PubMed]

114. Sabia, S.; Fayosse, A.; Dumurgier, J.; Dugravot, A.; Akbaraly, T.; Britton, A.; Kivimaki, M.; Singh-Manoux, A. Alcohol consumption and risk of dementia: 23 year follow-up of Whitehall II cohort study. BMJ 2018, 362, k2927. [CrossRef] [PubMed]

115. Ormstad, H.; Rosness, T.A.; Bergem, A.L.M.; Bjertness, E.; Strand, B.-H. Alcohol consumption in the elderly and risk of dementia related death-A Norwegian prospective study with a 17-year follow-up. Int. J. Neurosci. 2006, 126, 135-144. [CrossRef]

116. Hu, M.; Corkill, R. Population studies highlight an increased risk of dementia in both dependent and non-dependent drinkers. J. Neurol. 2019, 266, 790-792. [CrossRef]

117. Dikalov, S.; Itani, H.; Richmond, B.; Arslanbaeva, L.; Vergeade, A.; Jamshedur-Rahman, S.M.; Boutaud, O.; Blackwell, T.; Massion, P.P.; Harrison, G.D.; et al. Tobacco smoking induces cardiovascular mitochondrial oxidative stress, promotes endothelial dysfunction, and enhances hypertension. Am. J. Physiol. Heart Circ. Physiol. 2019, 316, H639-H646. [CrossRef]

118. Batty, G.D.; Shipley, M.J.; Kvaavik, E.; Russ, T.; Hamer, M.; Stamatakis, E.; Kivimaki, M. Biomarker assessment of tobacco smoking exposure and risk of dementia death: Pooling of individual participant data from 14 cohort studies. J. Epidemiol. Community Health 2018, 72, 513-515. [CrossRef] 
119. Choi, D.; Choi, S.; Park, S.M. Effect of smoking cessation on the risk of dementia: A longitudinal study. Ann. Clin. Transl. Neurol. 2018, 5, 1192-1199. [CrossRef]

120. Steven, S.; Frenis, K.; Oelze, M.; Kalinovic, S.; Kuntic, M.; Bayo-Jimenez, T.M.; Vujacic-Mirski, K.; Helmstadter, J.; Kroller-Schon, S.; Munzel, T.; et al. Vascular Inflammation and Oxidative Stress: Major Triggers for Cardiovascular Disease. Oxidative Med. Cell. Longev. 2019, 2019, 1-26. [CrossRef]

121. Elias, A.; Cummins, T.; Tyrrell, R.; Lamb, F.; Dore, V.; Bobert, W.; Rosenfeld, J.V.; Hopwood, M.; Villemagne, L.V.; Rowe, C.C. Risk of Alzheimer's disease in obstructive sleep apnea syndrome: Amyloid- $\beta$ and Tau imaging. J. Alzheimers Dis. 2018, 66, 733-741. [CrossRef]

122. Przybylska-Kuć, S.; Zakrzewski, M.; Dybata, A.; Kicinski, P.; Dzida, G.; Myslinski, W.; Prystupa, A.; Mosiewicz-Madejska, B.; Mosiewicz, J. Obstructive sleep apnea may increase the risk of Alzheimer's disease. PLoS ONE 2019, 14, e0221255. [CrossRef]

123. Hahn, E.A.; Wang, H.-X.; Andel, R.; Fratiglioni, L. A change in sleep pattern may predict Alzheimer disease. Am. J. Geriat. Psychiatry 2014, 22, 1262-1271. [CrossRef] [PubMed]

124. Liguori, C.; Mercuri, N.B.; Nuccetelli, M.; Izzi, F.; Cordella, A. Obstructive sleep apnea may induce orexinergic system and cerebral $\beta$-amyloid metabolism dysregulation: Is it a further proof for Alzheimer's disease risk? Sleep Med. 2019, 56, 171-176. [CrossRef] [PubMed]

125. Marchand, D.G.; Postuma, R.B.; Escudier, F.; Roy, J.; Pelletier, A.; Montplaisir, J. How does dementia with Lewy bodies start? Prodromal cognitive changes in REM sleep behavior disorder. Ann. Neurol. 2018, 83, 1016-1026. [CrossRef]

126. Alzheimer's Association. Surprising Differences Found in How Sleep Medications Increase Dementia Risk for Some, Protect Others. Available online: https://www.prnewswire.com/news-releases/surprising-differencesfound-in-how-sleep-medications-increase-dementia-risk-for-some-protect-others-300884450.html (accessed on 15 July 2019).

127. Richards, K.C.; Goonerante, N.; Dicicco, B.; Hanlon, A.; Moelter, S.; Onen, F.; Wang, Y.; Sawyer, A.; Weaver, T.; Lozano, A.; et al. CPAP Adherence May Slow 1-Year Cognitive Decline in Older Adults with Mild Cognitive Impairment and Apnea. J. Am. Geriatr. Soc. 2019, 67, 558-564. [CrossRef] [PubMed]

128. Weier, M.; Hall, W. The use of cannabinoids in treating dementia. Curr. Neurol. Neurosci. 2017, 17, 56. [CrossRef]

129. Chiu, H.-L.; Chu, H.; Tsai, J.-C.; Liu, D.; Chen, Y.-R.; Yang, H.-L.; Chou, K.-R. The effect of cognitive-based training for healthy older people: A metanalysis of randomized controlled trials. PLOS ONE 2017, 12, e0176742. [CrossRef]

130. Rabinovici, G.D.; Carrillo, M.C.; Forman, M.; DeSanti, S.; Miller, D.S.; Kozauer, N.; Petersen, C.R.; Randolph, C.; Knopman, S.D.; Smith, E.E.; et al. Multi comorbid neuropathologies in the setting of Alzheimer's disease neuropathology and implications for drug development. Alzheimers Dement. 2017, 3, 83-91. [CrossRef]

131. Wang, Z.; Marseglia, A.; Shang, Y.; Dintica, C.; Patrone, C.; Xu, W. Leisure activity and social integration mitigate the risk of dementia related to cardiometabolic diseases: A population-based longitudinal study. Alzheimers Dement. 2019, in press. [CrossRef]

132. Liang, J.-H.; Xu, Y.; Lin, L.; Jia, R.-X.; Zhang, H.-B.; Hang, L. Comparison of multiple interventions for older adults with Alzheimer disease or mild cognitive impairment. Medicine 2018, 97, e10744. [CrossRef]

133. Ngandu, T.; Lehtisalo, J.; Solomon, A.; LevälahtI, E.; Ahtiluoto, S.; Antikainen, R.; Backman, L.; Hanninen, T.; Jula, A. A 2 year multidomain intervention of diet, exercise, cognitive training, and vascular risk monitoring versus control to prevent cognitive decline in at-risk elderly people (FINGER): A randomised controller trial. Lancet 2015, 385, 2255-2263. [CrossRef]

134. Moll van Charante, E.P.; Richard, E.; Eurelings, L.S.; van Dalen, J.-W.; Ligthart, S.A.; Bussel, E.F.V.; Hoevenaar-Bol, M.P.; Vermeulen, M.; Gool, W.A.V. Effectiveness of a 6-year multidomain vascular care intervention to prevent dementia (preDIVA): A cluster-randomised controlled trial. Lancet 2016, 388, 797-805. [CrossRef]

135. Andrieu, S.; Guyonnet, S.; Coley, N.; Cantet, C.; Bonnefoy, M. Effect of long-term omega 3 polyunsaturated fatty acid supplementation with or without multidomain intervention on cognitive function in elderly adults with memory complaints (MAPT): A randomised, placebo-controlled trial. Lancet 2017, 16, 377-389. [CrossRef]

136. Eggink, E.; Moll van Charante, E.P.; van Gool, W.; Richard, E. A population perspective on prevention of dementia. J. Clin. Med. 2019, 8, 834. [CrossRef] [PubMed] 
137. Leorin, C.; Stella, E.; Nugent, C.; Cleland, I.; Paggetti, C. The value of including people with dementia in the co-design of personalized eHealth technologies. Dement. Geriatr. Cogn. Disord. 2019, 47, 164-175. [CrossRef] [PubMed]

138. Iacono, D.; Markesbery, W.R.; Gross, M.; Pletnikova, O.; Rudow, G.; Zandi, P.; Troncoso, J.C. The Nun Study: Clinically silent AD, neuronal hypertrophy, and linguistic skills in early life. Neurology 2009, 73, 665-673. [CrossRef] [PubMed]

Publisher's Note: MDPI stays neutral with regard to jurisdictional claims in published maps and institutional affiliations.

(C) 2020 by the authors. Licensee MDPI, Basel, Switzerland. This article is an open access article distributed under the terms and conditions of the Creative Commons Attribution (CC BY) license (http://creativecommons.org/licenses/by/4.0/). 